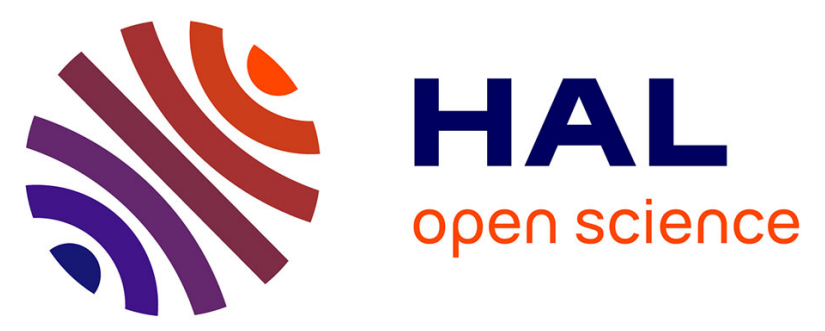

\title{
Differential Brain, Cognitive and Motor Profiles Associated with Partial Trisomy. Modeling Down Syndrome in Mice
}

Pierre L. Roubertoux, Nathalie Baril, Pierre Cau, Christophe Scajola, Adeline Ghata, Catherine Bartoli, Patrice Bourgeois, Julie Di Christofaro, Sylvie Tordjman, Michèle Carlier

\section{To cite this version:}

Pierre L. Roubertoux, Nathalie Baril, Pierre Cau, Christophe Scajola, Adeline Ghata, et al.. Differential Brain, Cognitive and Motor Profiles Associated with Partial Trisomy. Modeling Down Syndrome in Mice. Behavior Genetics, 2017, 47 (3), pp.305-322. 10.1007/s10519-017-9835-5 . hal-01614900

\author{
HAL Id: hal-01614900 \\ https://hal.science/hal-01614900
}

Submitted on 11 Oct 2017

HAL is a multi-disciplinary open access archive for the deposit and dissemination of scientific research documents, whether they are published or not. The documents may come from teaching and research institutions in France or abroad, or from public or private research centers.
L'archive ouverte pluridisciplinaire HAL, est destinée au dépôt et à la diffusion de documents scientifiques de niveau recherche, publiés ou non, émanant des établissements d'enseignement et de recherche français ou étrangers, des laboratoires publics ou privés. 


\section{Differential Brain, Cognitive and Motor Profiles Associated with Partial Trisomy. Modeling Down Syndrome in Mice}

Pierre L. Roubertoux, 1 ,

Phone +33(0)4 91324564

Email Pierre.ROUBERTOUX@univ-amu.fr

Nathalie Baril, ${ }^{2}$

Pierre Cau, 1,3,4

Christophe Scajola, 1

Adeline Ghata, 1

Catherine Bartoli, 1

Patrice Bourgeois, 1,3

Julie di Christofaro, 5

Sylvie Tordjman, 6,7

Michèle Carlier, ${ }^{8}$

1 Aix Marseille University, INSERM, UMR_S 910, GMGF, TIMONE -

27 Boulevard Jean Moulin, 13005 Marseille, France

2 Department 3C, Aix Marseille University, CNRS, Marseille, France

3 Department of Medical Genetics, AP-HM, Timone Hospital, Marseille, France

4 Service de Biologie Cellulaire, AP-HM, Hôpital La

Timone, 13385 Marseille Cedex 5, France

5 Aix Marseille University, CNRS, EFS, ADES, Marseille, France 
6 Paris Descartes University, CNRS, LPP, Paris, France

7 Rennes 1 University, PHUPEA, Rennes, France

8 Aix Marseille University, CNRS, LPC, Marseille, France

\section{Abstract}

We hypothesize that the trisomy 21 (Down syndrome) is the additive and interactive outcome of the triple copy of different regions of HSA21. Because of the small number of patients with partial trisomy 21, we addressed the question in the Mouse in which three chromosomal regions located on MMU10, MMU17 and MMU16 carries almost all the HSA21 homologs. Male mice from four segmental trisomic strains covering the D21S17-ETS2 (syntenic to MMU16) were examined with an exhaustive battery of cognitive tests, motor tasks and MRI and compared with TS65Dn that encompasses D21S17-ETS2. None of the four strains gather all the impairments (measured by the effect size) of TS65Dn strain. The 152F7 strain was close to TS65Dn for motor behavior and reference memory and the three other strains 230E8, $141 \mathrm{G} 6$ and 285E6 for working memory. Episodic memory was impaired only in strain 285E6. The hippocampus and cerebellum reduced sizes that were seen in all the strains indicate that trisomy 21 is not only a hippocampus syndrome but that it results from abnormal interactions between the two structures.

\section{Keywords}

D21S17-ETS2 region

Trisomy 21

Down syndrome

Mouse

Ts65Dn

Hippocampus

Cerebellum

Morris water maze

Tonicity

Gait 
working memory

reference memory

MRI

Protein-protein interactions

Effect size.

\section{Introduction}

Down syndrome, with an extra copy of HSA21, and also known as trisomy 21 (TRS21), has been characterized in a set of 25 traits (Jackson et al. 1976), but with incomplete penetrance. $45-50 \%$ of the patients have heart malformations (Vis et al. 2009). Incomplete penetrance is also the case for leukemia which is 4-5 times more prevalent in TRS2 1 than in the general population (Boker et al. 2001; Janzen et al. 2015; Mezei et al. 2014). Intellectual disability (ID) is the main characteristic of people with TRS21. With only a few exceptions, IQ test scores are less than 70 (i.e. below the normal range threshold). Mean IQ scores for persons with TRS21, between 40 and 50 (Breia et al. 2014; Carlier et al. 2011; Carr 2012) is only an estimate, as scores are influenced by demographic characteristics of the study sample (e.g. age or the institutional environment) and the lowest score of the IQ test used (40 or 45 on the Wechsler scales, but lower for other tests). Further bias often occurs for the mean IQ as many individuals with TRS21 record a minimum score (Carlier and Roubertoux 2014; Couzens et al. 2011; Roubertoux and Carlier 2009; Tsao and Kindelberger 2009) while others cannot be assessed because of their poor language skills and/or the severity of their behavioral disorders. Attention, learning, planning, cognitive flexibility, memory and linguistic abilities are affected (Costanzo et al. 2013; Grieco et al. 2015; Lanfranchi et al. 2010; Vicari 2006 ). Of the 25 traits used to draw up the clinical picture of TRS2 1 (Jackson et al. 1976), intellectual disability is therefore the only one with near-complete penetrance (Antonarakis et al. 2004; Grieco et al. 2015), which makes the discovery of chromosome 21 (HSA21) genes associated with ID the main challenge of research on TRS21. It is difficult to identify the HSA21 genes with their triple copy being associated with ID because of the small number of segmental trisomies (Higurashi et al. 1990; Poissonnier et al. 1976). Another difficulty is the heterogeneity of the cognitive profile as some cognitive processes are strongly impacted while others are less impaired (Chapman and Hesketh 2001; Lavenex et al. 
2015; Patterson et al. 2013; Vicari and Carlesimo 2006). This heterogeneity and the lack of validity of certain cognitive measures can explain discrepancies between studies (Delabar et al. 1993; Korenberg et al. 1994; Lyle et al. 2009).

The mouse model provides an option for overcoming the problem of the small number of segmental trisomies in Man. HSA21 encompasses between 210 (Hattori et al. 2000) and 283 protein-coding genes (Watanabe et al. 2004). Most are orthologs to mouse genes and are located on three syntenic regions: MMU10, MMU16 and MMU17.The estimated number of genes carried by the three regions varies according to the sequencing method and to the criteria. MMU10, MMU16 and MMU17 included nearly 41, 113 and 19 orthologs respectively (Fig. 1 a). No involvement of a triple copy of MMU10, between Pdxk and Prmt2,, $\mathrm{Vu}$ et al. 2010a) (see Fig. 1 g) has been found in cognitive performance. A Inple copy of MMU17 (limited by Abcgl and U2afl (Pereira et al. 2009) - Fig. 1 I-or by Abcgl and Rrplb (Yu et al. 2010a) Fig. 1j) had no effect on cognitive performances. If a triple copy of MMU17 alone does not impair cognition, two MMU17 copies are necessary for rescuing the wild phenotype of MMU16 in full mouse model gathering the 10,16 and 17 regions (Zhang et al. 2014). But an extra copy of the telomeric end of MMU16 alone generates brain abnormalities and cognitive deficit. The segmentally trisomic strain Ts65Dn that carries a Robertsonian translocation of nearly all the MMU16 genes (from Mrpl-39 to Znf295) excluding the Lipi to Mrpl-39 region (Fig. 1 b, h) is associated with cognitive deficit, as reported in more than 30 studies (Roubertoux and Carlier 2009; Seregaza et al. 2006).

\section{Fig. 1}

Mouse models of TRS21 produced by triplicating a mouse chromosome fragment, with the names of the genes bounding the fragments $(\mathbf{a}-\mathbf{j}) . \mathbf{a}$ Syntenic regions of HS21 in the mouse genome (MMU10, MMU16 and MMU17). b Ts65Dn strain (Davisson et al. 1990; Reeves et al. 1995). c MS1Ts65 (Sago et al. 1998). d TsCje (Sago et al. 2000). e Ts1Rhr (Olson et al. 2007). f Euploid mice for the Ts1Rhr region only (Belichenko et al. 2009; Olson et al. 2007). g Dp(10)1 Yey/+, mice trisomic for MMU10 (Yu et al. 2010a, b). h Dp(16) Yu, mouse trisomic for MMU16 (Yu et al. 2010a, b). i TsYah, mouse trisomic for 12 genes in the MMU17 region (Pereira et 
al. 2009). j Dp(17)1Yey/+, mouse trisomic for the MMU17 region (Yu et al. $2010 \mathrm{a}, \mathrm{b}$ )

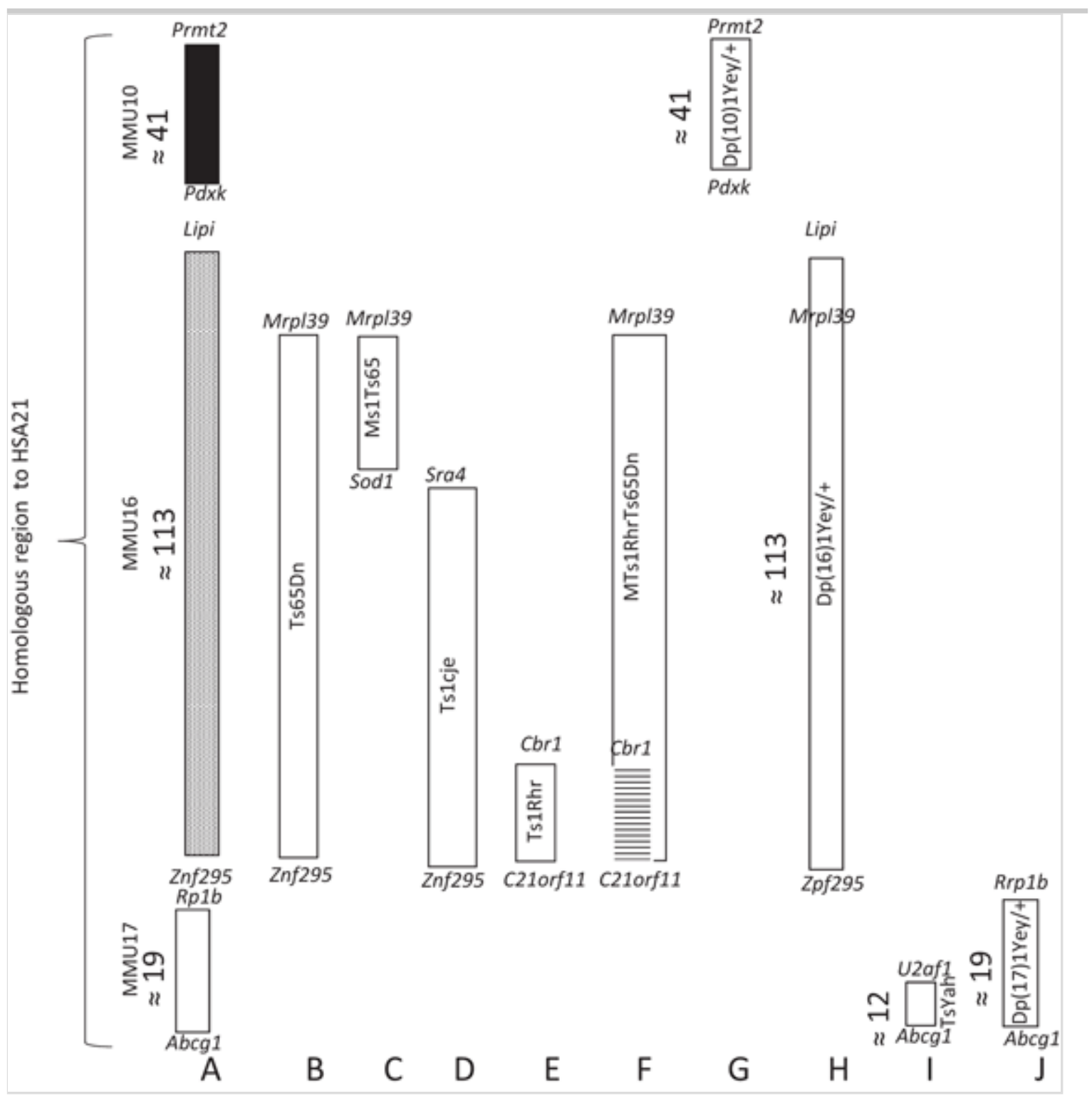

The genes contributing to the brain and cognitive defects of a triple MMU16 seem located to its telomeric end. When the Ts65Dn was split producing two partial strains, Ms1Ts65 and Ts1cje (Fig. 1 c, d), cognitive deficits were observed only with the telomeric part of Ts1 cje (Sago et al. 1998, 2000). The telomeric part of Ts1cje is also telomeric on Ts65Dn and contains a region corresponding to the $21 \mathrm{q} 22.1$ and $21 \mathrm{q} 22.3$ cytological bands of HSA21 that is overlapped by the D21S17-ETS2 human region. One of the segmental trisomic mice with human fragments covering the D21S17-ETS2 region shows cognitive defect (Chabert et al. 2004; Smith et al. 1997). When the same fragments were incorporated in euploid mice (Fig. 1 e), it was expected that the Cbrl to C21orf11 segment 
encompassing the D21S17-ETS2 syntenic region would lower both synaptic plasticity and cognitive performance; and the reverse was expected when the Cbrl to C21orfl1 segment was removed from trisomic mice (Fig. 1f), but this was not the case. Olson and colleagues did not observe cognitive impairment in the mice with the Morris Water Maze (MWM), or with long-term potentiation (Olson et al. 2004). Unexpectedly, data from another study of the same group provided evidence linking the Cbrl to C21orfl1 triple copy with cognitive deficit when testing other cognitive tasks (alternation task and novel object recognition) (Olson et al. 2007). Differences between the cognitive processes tested in the two studies may contribute to discrepancies in the findings results.

We hypothesize that a triple copy of a HSA21 syntenic fragment that generates ID does not impact all the cognitive functions. We assume, in other words, that the segmental trisomic mice have different profile for cognition, motor behavior and brain structures that are impaired in TRS21. We therefore chose to use tests to produce a wide range of cognitive measures, following the analyze by Milner, Squire and Kandel (Milner et al. 1998). We also tested motor activity as atypical motor development was included in traits reported by Jackson (Jackson et al. 1976); and we performed volumetric measurement of brain structures as observations of human patients showed the HSA21 triple copy to have a strong effect on a number of brain structures (Menghini et al. 2011; Roubertoux and Carlier 2009). We used four strains of mice integrating extra copies of fragments covering D21S17-ETS2 (Smith et al. 1997) to test the heterogeneous profile hypothesis. These four were compared with both euploids and Ts65Dn mice because it encompasses the D21S17-ETS2 segmental strains.

\section{Materials and methods}

\section{Mice}

The first group of mice is the Ts65Dn strain carrying a Robertsonian translocation of a MMU16 fragment (Davisson et al. 1990) bounded by Mrpl39 and Znf295 and encompassing approximately 113 genes (Antonarakis et al. 2004). We used C57Bl/6JEi x C3H/HeJ. F2 as controls (Coussons-Read and Crnic 1996). Ts65Dn and C57Bl/6 J x C3H/HeJ controls were supplied by The Jackson Laboratory. The second group had four strains each carrying a fragment of human chromosome 21 (HAS 21) 
covering the D21S17-ETS2 region (Fig. 2 a). Each strain had two sub-strains replicating the same HSA21 fragment. We selected sub-strains $50,4,12$ and 67 to cover the D21S17-ETS2 region as they carry only one extra copy of the HSA21 fragment and are therefore more relevant for modeling the syndrome. The mice with an extra fragment from HSA21 have an FVB background. They are albino and they carry a recessive mutation causing retinal degeneration. By the age of 3 months they are blind. One prerequisite for the experiment was to cross blind and albino FVB males with C57BL/6 females that have pigmented eyes and that did not have the mutation as most of the cognitive tasks involved visual cues. The euploid controls (C57BL/6 x FVB) were non-transgenic littermates. They were compared with the $\mathrm{C} 57 \mathrm{~B} 1 / 6 \mathrm{~J}$ x C3H/HeJ for each measure.

\section{Fig. 2}

Segmental trisomies of the D21S17-ETS2 region (a, b). a Segmental trisomies 21 produced by inserting human contiguous fragments in the D21S17-ETS2 region of HSA21 (Smith et al. 1997). b Interactions between the proteins encoded by these genes as resulting from the analysis of the 14 proteins encoded by the D21S17-ETS2 segmental trisomies with String (Szklarczyk et al. 2015) 


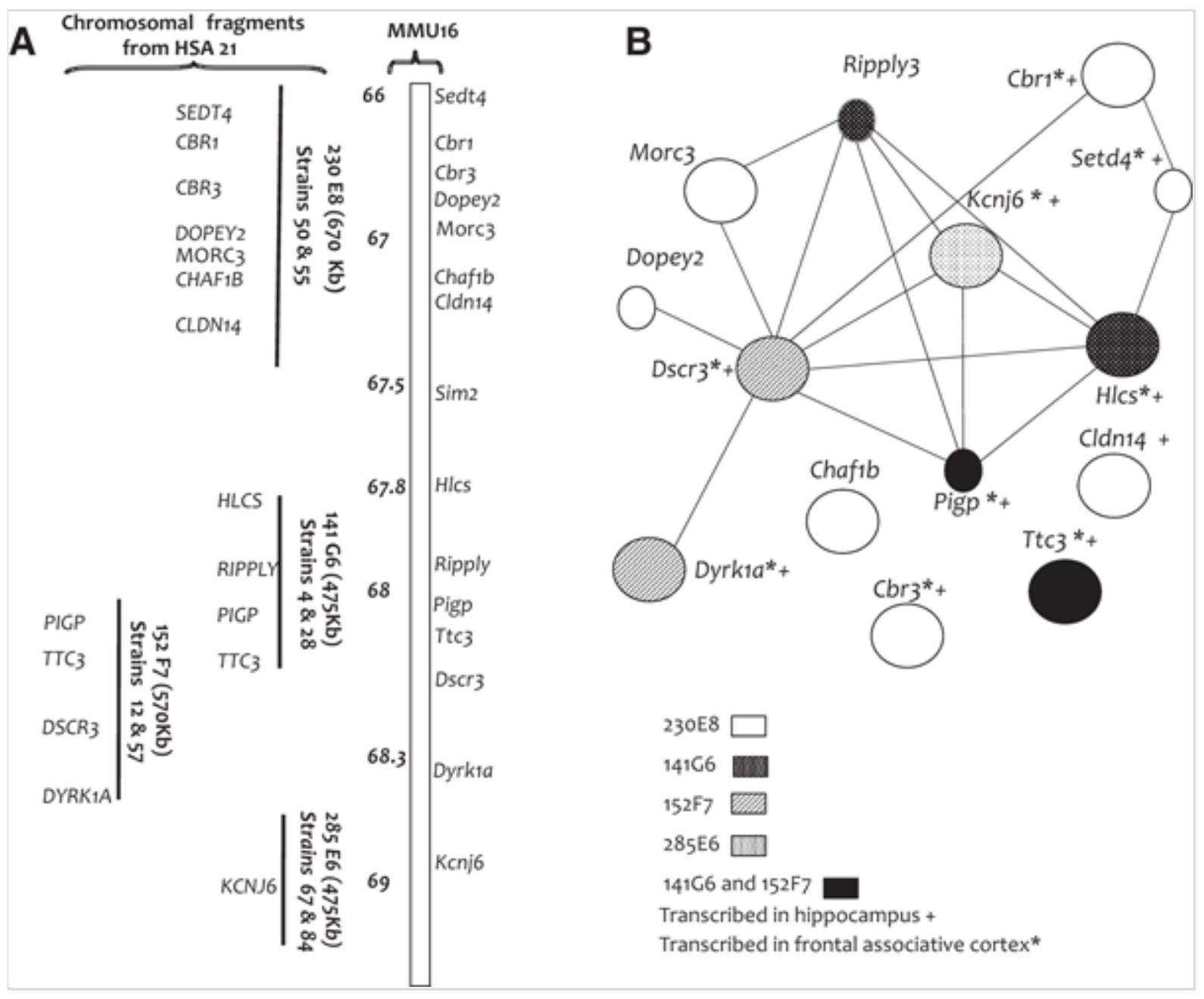

The C57BL/6 mice were purchased from Charles River France; the 230E8, 141G6, 152F7 and 285E6 breeders were kindly donated to P.L. Roubertoux by Ed. Rubin and were from the European Mouse Mutant Archive (EMMA). EMMA ID for breeders: 01302-01304, 01237, 01238, 01245, 01246, 01748 ( https://www.infrafrontier.eu/search ). Genotyping was done by PCR using the primers as described by D. Smith and as previously reported (Chabert et al. 2004).

The testing schedule was designed to avoid the effects of excessive handling, learning transfer and fatigue. Batch 1 (62 mice, aged 85-107 days): open field, recognition of novel object; batch 2 (78 mice, 88-99 days): radial maze, traction strength; batch 3 (79 mice, 92-100 days): fear conditioning, hind limb coordination and brain MRI; batch 4 (72 mice, 91-102 days): water maze, hole-board and batch 502 mice, 100-106 days): visible platform (water maze), sensorial testing and brain samples. The order of the tests was counterbalanced across mice within batch. Only male mice were tested in this study as no trisomic female was obtained in the strains 152F7 and 141G6. The design included 
363 male mice. Sample sizes are detailed in the captions to diagrams.

\section{Housing}

Grouped males display frequently agonistic behavior (Ginsburg BE 1942; Maxson and Canastar 2003 ). Males with B6.FVB background display aggressive behavior and they could not be housed together. Social isolation generates undesirable physiological and brain effects that can be permanent (Volden et al. 2013). Each male to be tested was housed with a female to avoid these biases. Transparent $35 \times 20 \times 18 \mathrm{~cm}$ cages were used with woodchip poplar bedding, dome house for enrichment, food (Harlan Global Diet 2018) and water $a d$ lib and a 12/12 light/dark period with lights on at 7 AM.

\section{Transcription of the genes carried by euploids, and the 230E8, 141G6, 152F7 and 285E6 strains}

We limited the analysis to the hippocampus and the frontal association cortex, known for their implication in cognitive functions. All brain dissections were made on ice. We first extracted the hippocampus from six mice in each segmental trisomic strain and from 24 euploid mice. The same numbers were used for the frontal association cortex, obtained by coronal section as described (Palkovits and Brownstein 1988). The whole brain was placed on the refrigerated platform of a manual cryostat. We retrieved a large slice from bregma 3.20 to bregma 2.58, Fig. 04 to 09 of the stereotaxic atlas (Paxinos and Franklin 2004) then took four fragments per slice using a micro-dissection needle (trocar diameter $1 \mathrm{~mm}$ ) from the frontal association cortex in the upper peripheral part of the brain. The brain samples were preserved in liquid nitrogen. Validation of the microdissection was done after fixation of the bregma 3.20-bregma 2.58 slice in paraformaldehyde, $20 \mu$-thick slide slicing and cresyl violet acetate from Sigma, staining and examination under microscope. We performed RNA extraction with the RNeasy Lipid Tissue Mini Kit (QIAGEN).

Hybridization of the RNA (one euploid mouse and one segmental trisomic) was performed with the Whole Mouse Genome Microarray Amp Labeling Kit, Two-Color Kit (Agilent Technologies). The transcripts were counted, controlled and normalized as previously described (Bourgeois and Roubertoux 2015). Within-strain comparisons were performed on euploid and co-hybridized trisomic mice (matched student $t$ ) and the comparison 
was expressed as $\log 2$ of the mean value of the ratio number of transcripts in segmental trisomic mice/number of transcripts in segmental euploid mice.

\section{Interactions between proteins coded by genes in the D21517-ET52 region}

Proteins encoded by the genes on the four fragments were entered into the Search Tool for the Retrieval of Interacting Genes/Proteins (STRING), and we detected interactions between proteins above the medium confidence threshold (Szklarczyk et al. 2015).

\section{Control for sensorial impairment}

We controlled mice for visual, auditory and pain perception according to the protocols previously presented (Caubit et al. 2016).

\section{Cognitive measures}

We selected six cognitive tasks to cover the processes underlying the memory classification of Milner, Squire and Kandel (Milner et al. 1998). Reference memory was measured by the ability to locate the platform in the MWM. Working memory was measured by the number of errors in a version of the 8-arm radial maze (RAM) (Liu et al. 2011; Matynia et al. 2002 ). Episodic memory was assessed using the novel object recognition test (Ennaceur and Delacour 1988; Lyon et al. 2012). For associative memory we used cued conditioning in the emotional response test. For discriminative memory we used the altered context version of the fear-conditioning test (Contarino et al. 2002). We add the exploratory behavior that plays a crucial role in learning (Arenas et al. 2014; Sanderson and Bannerman 2011). It was assessed using an automatic hole-board.

The $M W M$ measures a mouse's ability to find a submerged resting platform (P) concealed beneath opaque water, an exercise requiring the use of extra-maze visual cues which are provided in the room (Upchurch and Wehner 1988). The platform was a glass cylinder (7 cm diameter) positioned $25 \mathrm{~cm}$ from the edge of a $100 \mathrm{~cm}$ diameter circular tank filled with water $26 \pm 1{ }^{\circ} \mathrm{C}$ and light at $70 \mathrm{~lx}$ on the surface. Each mouse performed 2 blocks of 4 trials each, every day for 4 successive days: one 
shaping block (data not included here) and 7 test blocks. A trial lasted $90 \mathrm{~s}$ when the mouse failed to reach the platform. We considered that the mouse had reached the platform when it stayed on the platform for $5 \mathrm{~s}$ at least. At the end of a trial, we presented a small metal shelf to the mouse (in water or on the platform) that climbed on it and was transferred in a cage with dry sawdust for $120 \mathrm{~s}$. We had previously assigned four virtual cardinal points to the tank, each being the starting point for a trial. The starting point for each trial was chosen randomly and within a block the mouse never started more than once from the same virtual cardinal point. We measured and reported the "time to reach the hidden platform" (P) over 7 blocks. Strains can achieve different performance levels between blocks, but without a cumulative reduction in the time to reach the platform, which is the criterion to identify learning process. We computed and reported "the slopes of the learning curves", a negative and significant slope indicating learning behavior. The probe-test procedure, conducted after removing the platform, was done $24 \mathrm{~h}$ after block 7 to meet the requirements for reference memory and lasted $90 \mathrm{~s}$. The mouse was placed in the center of the tank, and we measured the time of first crossing the virtual annulus corresponding to $\mathrm{P}$. The variable is reported as the "latency to reach the $\mathrm{P}$ " virtual platform". Time spent in the quadrant containing the platform is generally reported as an indicator of the ability to locate the platform, but we did not use that index as it gave the same scores for regions of the quadrant that were not equidistant from the center of the platform, and also because it interferes with thigmotaxis. We measured activity on the virtual $\mathrm{P}$ " region, concentric to $\mathrm{P}$ and covering the same surface area (radius: $25 \mathrm{~cm}$ ) as a quadrant. The measure included the number of visits in P'. It was labeled "number of visits in P" during the probe test". We subjected a group of naïve mice to the visible-platform version of the test, with the platform $5 \mathrm{~mm}$ above non-opacified water to check whether the differences in the time to reach the platform were due to vision and/or swimming abilities rather than learning ability. The score was reported as "time to reach the visible platform". The measure of swimming ability in the MWM was calculated during the 90 s of the probe test: "distance swum" expressed in $\mathrm{mm}$. The time to reach the platforms was automatically measured using a Video track setup (Viewpoint- Behavior technologies: http://www.viewpoint.fr/news.php ).

The RAM 9 sisted in finding a food pellet in each of eight arms of the 
maze by using extra-maze visual cues. The male mice were previously subjected to a diet until it reached $90 \%$ of its initial body weight when the learning experiment started. Briefly, a tested male was housed in an individual cage and it received a small quantity of pellet (between 4 to $7 \%$ of the initial body weight). The males were weighted and fed daily at 7 PM. They were housed in a new clean cage to prevent food hoarding. The amount of food was daily adjusted to the body weight reached by the mouse. Mice were habituated to the maze on the first day, then trained for 5 days (Roubertoux et al. 2003). An error was counted when the mouse entered an arm it had already explored in the same session (Hodges 1996). Data describe the learning performance during five consecutive days. We report the slope of the learning curve and the total number of errors.

We used a modified Ugo Basile fear conditioning system for altered context and cued fear conditioning with the protocol over two successive days as used by (Wehner and Radcliffe 2004). On day 1, the mouse was placed in the plastic box fit with a loudspeaker emitting a composite sound of $70 \mathrm{db}$ and an electrified grid floor connected to a constant current shocker: current from 0.1 to $2.9 \mathrm{~mA}$ in $0.1 \mathrm{~mA}$ steps. Light was $40 \mathrm{~lx}$ at ground level. The mouse was allowed to explore the box for $5 \mathrm{~min}$, and was then subjected to the sound for $20 \mathrm{~s}$, followed by a $2 \mathrm{~s}$ pause, then an electric stimulus $(0,9 \mathrm{~mA})$ lasting $2 \mathrm{~s}$. The paired sound-electric shock was repeated $120 \mathrm{~s}$ later. On day 2 , the mouse was placed in the modified box where a removable partition had halved the surface area (altered context) and was left there for $300 \mathrm{~s}$. The mouse was then taken back to its home cage. One hour later it was placed in the non-modified box and subjected to a $20 \mathrm{~s}$ sound. We recorded the number of freezing episodes during the $300 \mathrm{~s}$ in the altered context and during the $300 \mathrm{~s}$ after the sound was emitted in the non-modified box. A freezing episode was defined as the absence of any movement except for respiration. We choose to measure the number of freezing because of its high reliability (Wehner et al. 1997). The altered context conditioning score (discriminative memory) was the difference between the number of freezing episodes in the $300 \mathrm{~s}$ prior to the first auditory stimulus (day 1) and the number of freezing episodes in the $300 \mathrm{~s}$ spent in the altered context (day 2). The "cued associative conditioning score" (associative learning) was the difference between the number of freezing episodes in the $300 \mathrm{~s}$ prior to the first auditory stimulus (day 1) and the number of freezing episodes in $300 \mathrm{~s}$ after the auditory 
stimulus (day 2) (Wehner and Radcliffe 2004; Wehner et al. 1997).

The novel object recognition test is based on the observation that the replacement of a familiar object by a new object induces an over-exploration of the object by rodents. The number of contacts when exploring expresses the intensity of the recollection (Ennaceur and Delacour 1988). Two identical $3 \times 2 \mathrm{~cm}$ washable plastic objects were placed in an arena with low lighting ( $65 \mathrm{~lx}$ at ground level). The mouse was left free to explore the setup for $10 \mathrm{~min}$. Twenty-four hours later, the mouse was put in the same experimental conditions, but one of the two objects had been replaced by a differently shaped object. The number of contacts when exploring (nose contact with an object) was counted for each object. The "novel object recognition score" was the number of contacts with the novel object minus the number of contacts with the familiar object (day 2).

Exploratory activity was measured using an automatic hole-board apparatus: a gray plastic board with four rows of four holes evenly spaced, $30 \mathrm{~mm}$ in diameter and each with a photocell. When a mouse dips the nose into a hole, it is automatically recorded on a digital meter; testing is done for $10 \mathrm{~min}$. This is reported as the "number of head dipping in the hole-board". The digital meter indicated the number of exploratory dips and we counted the number of stereotyped dips for each mouse according to previously published criteria (Irie et al. 2012; Makanjuola et al. 1977).

\section{Motor measures}

The Open field task exploring a novel environment measures motor performance (walking) and exploratory abilities. The field has a diameter of $100 \mathrm{~cm}$ and is bounded by a $60 \mathrm{~cm}$ high white cylinder (Denenberg 1969; Kafkafi et al. 2003); lighting is $230 \mathrm{~lx}$ at ground level and the area is divided virtually into three equal and concentric zones (Denenberg 1969 ). Mice were tested individually for $20 \mathrm{~min}$; we counted the number of rearing, leaning and grooming. The distance walked (in $\mathrm{mm}$ ) and the time spent in each of the three zones was measured using Videotrack from ViewPoint (Videotrack rodent behavior tracking software, ViewPoint, Lyon, France) over the full $20 \mathrm{~min}$ of the test.

Hind limb coordination is measured in the notched bar test used to assess 
gait impairment (number of hind paw slips) (Lipp P. and Wahlsten 1992). A solid bar with a smooth surface was used for shaping. Two experimenters stood either side of the carved bar to count the number of times the mouse slipped over five trials.

Traction strength was measured using the Ugo Basile Grip-Strength Meter. The mouse was placed over a grid base plate, with the grid connected to a force sensor connected to the Peak Amplifier. When the mouse is pulled by the tail, it grasps the grid. The mouse is positioned so that only the forepaws can reach the grid. Maximum traction strength is recorded at the moment when the mouse loses its grip. This is reported as "forelimb traction strength" and is expressed in gram-force.

\section{Brain magnetic resonance imaging (MRI)}

Volumetric properties of brain structures were measured using a 70/16 pharmascan spectrometer (BRUKER Biospin, Ettlingen, Germany) with a 7 - s magnet and $16 \mathrm{~cm}$ horizontal bore size after gaseous anesthesia of the mouse (induction air $2 \mathrm{~L} / \mathrm{min}+$ isoflurane $3 \%$ and maintenance via a nose-cone air $2 \mathrm{~L} / \mathrm{min}+$ isoflurane $2 \%$ ). We used 24 axial contiguous T2-weighted images (slice thickness $=0.5 \mathrm{~mm}$ ) with fat suppression (bandwidth $=900 \mathrm{~Hz}$ ) acquired from whole brain with a turbo-RARE sequence $(\mathrm{TEeff}=48 \mathrm{~ms}, \mathrm{TR}=3500 \mathrm{~ms}$, rare factor $=8,5$ averages $)$ with $19 \mathrm{~mm}$ Field Of View and $256 \times 256$ matrix. We acquired 24 coronal slices going from the olfactory bulb to the cerebellum. The structures were measured according to Cavalieri's principle of stereology adapted to brain volume. We used a computer-assisted method superimposing a grid with equidistant markers on the slice to calculate the surface area of the brain structure being measured. Volume was computed as follows: $\mathrm{V} \mathrm{mm}^{3}=\Sigma$ (area $\mathrm{x}$ ST), where $\Sigma$ area is the area of the slice, and was expressed as the number of markers encompassed in the area, transformed into $\mathrm{mm}^{2}$. ST was the thickness of the slice (mm). "Brain volume" was measured in $\mathrm{mm}^{3}$, and the volume of each structure was expressed as a percentage of the total brain volume and is reported as "hippocampus \%" and "striatum $\%$ ". The "cortex \%" covered the different cortices; "ventricle \%" covered the two lateral and the third ventricles, and "cerebellum \%" is the percentage of the cerebellum over the cerebrum (volume of brain + cerebellum). 


\section{Statistics}

Non-parametric statistics were chosen considering the non-normality of the distributions and the small sample sizes. Data analyses were done with Statistical Package for the Social Sciences (SPSS software, version 19). The results are shown as box-and-whisker diagrams presenting the median, the interquartile range (the box), the bottom and top quartiles (the lines under and above the box). Differences between more than two groups were computed with the Kruskal-Wallis non-parametric test and post-hoc group comparisons with the Mann-Whitney test. Because of the large number of comparisons and to reduce type 2 error, we only took into account $p$ values of $p \leq .01$. Differences between blocks in the MWM and between days in the RAM were tested for each group with Friedman ANOVA non-parametric test for related samples. The individual slope of the learning curve was obtained for each mouse by calculating a new score as the slope of the median values of the four trials in each of the seven blocks in the MWM, and as the slope of the number of errors of the 5 consecutive days in the RAM. The median slopes for the six groups were compared using the Kruskal-Wallis test and post-hoc comparisons with Mann-Whitney $U$ test.

The effect size was calculated after changing $U$ values into z scores (Field 2005 ) and was expressed as the percentage of the total variance of the dependent variable associated with differences between groups. We considered the effect size (Cohen 1988) rather than the probability of rejecting the null hypothesis because the validation of a model organism for a disorder not only requires a significant difference but also a large difference between the model and its controls. Values of $1.33 \sigma$ or $2 \sigma$ below the population mean were set as the criteria for diagnosing mild impairment and impairment, respectively. Expressed as effect size, these values are $\mathrm{R}^{2}=0.30$ (or $d=1.3$ ) and $\mathrm{R}^{2}=0.50$ (or $d=2$ ) for mild impairment and impairment respectively (Cohen 1988). For convenience $\mathrm{R}^{2}$ was expressed as percentage of the total variance of the dependent variable associated with difference between groups, i.e. $30 \%$ and $50 \%$ for mild impairment and impairment respectively.

\section{Results}


Nine protein-Coding genes were significantly over-transcribed in the frontal association cortex and ten in the hippocampus (Table 1) of the mice carrying extra fragments in the D21S17-ETS2 region. Figure $2 \mathrm{~b}$ indicates the site of transcription (hippocampus and cortex) of the genes according to their segmental location. The number of transcripts was the same in the Ttc3 and the Pigp genes independently of the fragment (141G6 and 152F7).

\section{Table 1}

Transcription of the genes carried by the 131E8, 142G6, 1523F7 or 2551E6 strains in the frontal associative cortex and in hippocampus after normalization

\begin{tabular}{|c|c|c|c|}
\hline $\begin{array}{l}\text { Gene } \\
\text { symbol }\end{array}$ & Gene name & $\begin{array}{l}\text { Frontal } \\
\text { associative } \\
\text { cortex }\end{array}$ & Hippocampus \\
\hline $\operatorname{Setd} 4$ & SET domain containing 4 & $1.93 *$ & $1.92 *$ \\
\hline Cbrl & carbonyl reductase 1 & $3.01 * *$ & $2.00 *$ \\
\hline Cbr3 & carbonyl reductase 3 & $1.94^{*}$ & $2.58 * *$ \\
\hline Dopey2 & dopey family member 2 & 0.43 & 0.61 \\
\hline Morc3 & microrchidia $2 \mathrm{~A}$ & 0.57 & 0.82 \\
\hline Chaflb & $\begin{array}{l}\text { chromatin assembly factor } 1 \text {, } \\
\text { subunit B }\end{array}$ & 1.14 & 1.07 \\
\hline Cldn14 & claudin 14 & 0.69 & $1.65^{*}$ \\
\hline Hlcs & holocarboxylase synthetase & $1.50 *$ & $1.45^{*}$ \\
\hline Ripply3 & ripply3 homolog (Zebrafish) & 0.92 & 0.05 \\
\hline Pigp & $\begin{array}{l}\text { phosphatidylinositol glycan } \\
\text { anchor biosynthesis, class P } \\
\text { (141 G6) }\end{array}$ & $2.44 * *$ & $2.50 * *$ \\
\hline Pigp & $\begin{array}{l}\text { phosphatidylinositol glycan } \\
\text { anchor biosynthesis, class P } \\
\text { (152 F7) }\end{array}$ & $2.67 * *$ & $2.21 * *$ \\
\hline Ttc3 & $\begin{array}{l}\text { tetratricopeptide repeat } \\
\text { domain } 3(141 \mathrm{G} 6)\end{array}$ & $1.50 *$ & $1.52 * *$ \\
\hline
\end{tabular}




\begin{tabular}{|c|c|c|c|}
\hline $\begin{array}{l}\text { Gene } \\
\text { symbol }\end{array}$ & Gene name & $\begin{array}{l}\text { Frontal } \\
\text { associative } \\
\text { cortex }\end{array}$ & Hippocampus \\
\hline Ttc3 & $\begin{array}{l}\text { tetratricopeptide repeat } \\
\text { domain } 3(152 \mathrm{~F} 7)\end{array}$ & $1.48 *$ & $1.78 * *$ \\
\hline Dscr3 & $\begin{array}{l}\text { Down syndrome critical region } \\
\text { gene } 3\end{array}$ & $1.61 * *$ & $1.50 *$ \\
\hline Dyrkla & $\begin{array}{l}\text { dual-specificity tyrosine- } \\
\text { (Y)-phosphorylation regulated } \\
\text { kinase 1a }\end{array}$ & $1.50 *$ & $2.31 * *$ \\
\hline Kcnj6 & $\begin{array}{l}\text { potassium inwardly-rectifying } \\
\text { channel, subfamily J, member } \\
6\end{array}$ & $1.85 * *$ & $1.93 * *$ \\
\hline
\end{tabular}

Figures $3,4,5,6,7$ and 8 present descriptive statistics on behavioral and brain variables, and also values for statistical significance of partial comparisons. The effect size of differences between the euploid group and each of the other groups $\left(\mathrm{R}^{2}\right)$ is in Table 2 and will be covered in the discussion section. The euploid groups $(\mathrm{C} 57 \mathrm{BL} / 6 \mathrm{~J} \times \mathrm{C} 3 \mathrm{H} / \mathrm{HeJ}$ and $\mathrm{C} 57 \mathrm{BL} / 6 \mathrm{JxFVB}$ male mice) did not differ and were therefore pooled in the following analyses.

\section{Table 2}

Size of the effect of the differences between the euploids and Ts65Dn and the segmental trangenics covering the D21S17-ETS2 region on cognition, volume of brain structures and motor behavior

\section{Behavioral and brain measures}

\section{Euploids compared to}

\section{\begin{tabular}{l|l|l|l|l} 
TS65Dn & 230E8 & 141G6 & 152F7 & 285E6
\end{tabular}}

$\mathrm{R}^{2}$ was expressed as a percentage of variance

Underlined and bold values correspond to mild impairment and impairment, respectively. $>$ and $<$ indicate the direction of the difference between the groups: > means that the score of the euploid group was higher. *Negative slope characterizes learning 


\section{Behavioral and brain measures}

Euploids compared to

\section{\begin{tabular}{|l|l|l|l|l|} 
TS65Dn & 230E8 & 141G6 & 152F7 & 285E6
\end{tabular}}

Cognition

Reference memory

Slope of the learning curves in MWM

$69(>) * \quad 08$

$64(>) \quad 71(>)$

26

Latency to reach the $\mathrm{P}^{\text {' }}$ virtual platform during the probe test

\begin{tabular}{l|l|l|l|l}
$\underline{48}(<)$ & 21 & 04 & 27 & 0.02
\end{tabular}

Number of visits in P" during the probe test

\begin{tabular}{|l|l|l|l|l}
$\mathbf{5 3}(>)$ & 00 & 05 & $\mathbf{6 9}(>)$ & 06
\end{tabular}

Working memory

\begin{tabular}{|c|c|c|c|c|c|}
\hline $\begin{array}{l}\text { Slope of the learning } \\
\text { curves in RAM }\end{array}$ & $71(>)^{*}$ & 28 & 00 & 01 & 02 \\
\hline $\begin{array}{l}\text { Numbers of errors in } \\
\text { RAM }\end{array}$ & $71(<)$ & $71(<)$ & $53(<)$ & 06 & $65(<)$ \\
\hline \multicolumn{6}{|l|}{ Associative memory } \\
\hline $\begin{array}{l}\text { Cued associative } \\
\text { conditioning score }\end{array}$ & 03 & 11 & 18 & 02 & 00 \\
\hline \multicolumn{6}{|l|}{ Discriminative memory } \\
\hline $\begin{array}{l}\text { Altered context } \\
\text { conditioning score }\end{array}$ & 26 & 18 & $\underline{39}(>)$ & 15 & 12 \\
\hline \multicolumn{6}{|l|}{ Episodic memory } \\
\hline $\begin{array}{l}\text { Novel object recognition } \\
\text { score }\end{array}$ & 00 & 20 & 07 & 13 & $\underline{44}(>)$ \\
\hline \multicolumn{6}{|l|}{ Exploratory behavior } \\
\hline $\begin{array}{l}\text { Number of head dipping } \\
\text { in the hole-board }\end{array}$ & $69(<)$ & 10 & 00 & $55(<)$ & 00 \\
\hline \multicolumn{6}{|l|}{ Cerebrum } \\
\hline Brain volume & $\underline{30(<)}$ & 00 & 00 & $\underline{42(<)}$ & 00 \\
\hline
\end{tabular}

$\mathrm{R}^{2}$ was expressed as a percentage of variance

Underlined and bold values correspond to mild impairment and impairment, respectively. $>$ and $<$ indicate the direction of the difference between the groups: $>$ means that the score of the euploid group was higher. ${ }^{*}$ Negative slope characterizes learning 


\begin{tabular}{|c|c|c|c|c|c|}
\hline \multirow{2}{*}{$\begin{array}{l}\text { Behavioral and brain } \\
\text { measures }\end{array}$} & \multicolumn{5}{|c|}{ Euploids compared to } \\
\hline & TS65Dn & $230 \mathrm{E} 8$ & $141 G 6$ & $152 F 7$ & 285E6 \\
\hline Cortex \% & $69(>)$ & 10 & 21 & 01 & $\underline{31}(<)$ \\
\hline Hippocampus \% & $69(>)$ & $55(>)$ & $\underline{42}(>)$ & $69(>)$ & $62(>)$ \\
\hline Ventricle \% & $69(<)$ & $\underline{42}(<)$ & $\underline{31}(<)$ & $69(<)$ & $\underline{42}(<)$ \\
\hline Striatum \% & 08 & 02 & 17 & 08 & 21 \\
\hline Cerebellum / cerebrum \% & $61(>)$ & 26 & $\underline{31}(>)$ & $55(>)$ & $62(>)$ \\
\hline \multicolumn{6}{|l|}{ Motor abilities } \\
\hline $\begin{array}{l}\text { Distance walked in open } \\
\text { field }\end{array}$ & 05 & 03 & 00 & 00 & $\underline{36}(>)$ \\
\hline Forelimb traction strength & $\mathbf{5 5}(>)$ & 27 & 13 & $63(>)$ & $\underline{35}(>)$ \\
\hline $\begin{array}{l}\text { Number of hind paw slips } \\
\text { on a notched bar task }\end{array}$ & $67(<)$ & 00 & 00 & $55(<)$ & 00 \\
\hline \multicolumn{6}{|c|}{$\mathrm{R}^{2}$ was expressed as a percentage of variance } \\
\hline \multicolumn{6}{|c|}{$\begin{array}{l}\text { Underlined and bold values correspond to mild impairment and impairment, } \\
\text { respectively. }>\text { and }<\text { indicate the direction of the difference between the } \\
\text { groups: }>\text { means that the score of the euploid group was higher. *Negative slope } \\
\text { characterizes learning }\end{array}$} \\
\hline
\end{tabular}

\section{Fig. 3}

Learning performance in Morris Water Maze of segmental trisomic strains of mice (A to F). a Median time - in $\mathrm{s}$ - to reach the hidden $\mathrm{P}$ platform in the course of 7 blocks of 4 trials each; asterisk indicates that the difference between blocks was significant independently of the shape of the curve; $\mathbf{b}$ slopes of learning curves over the 7 blocks; c latency to reach the virtual P' platform; d number of visits in the P" region during the probe test; e time to reach the visible platform. f Distance swum during the probe test. Sample size: $230 \mathrm{E} 8=141 \mathrm{G} 6=152 \mathrm{~F} 7=285 \mathrm{E} 6=\mathrm{Ts} 65 \mathrm{Dn}=10$ and euploids $=12$. Solid lines: 5 Dn vs other groups, doted lines: euploid vs other groups in $\mathrm{b}, \mathrm{c}, \mathrm{d}$ and f. ${ }^{*} p \leq .01, * * p \leq .001$ 

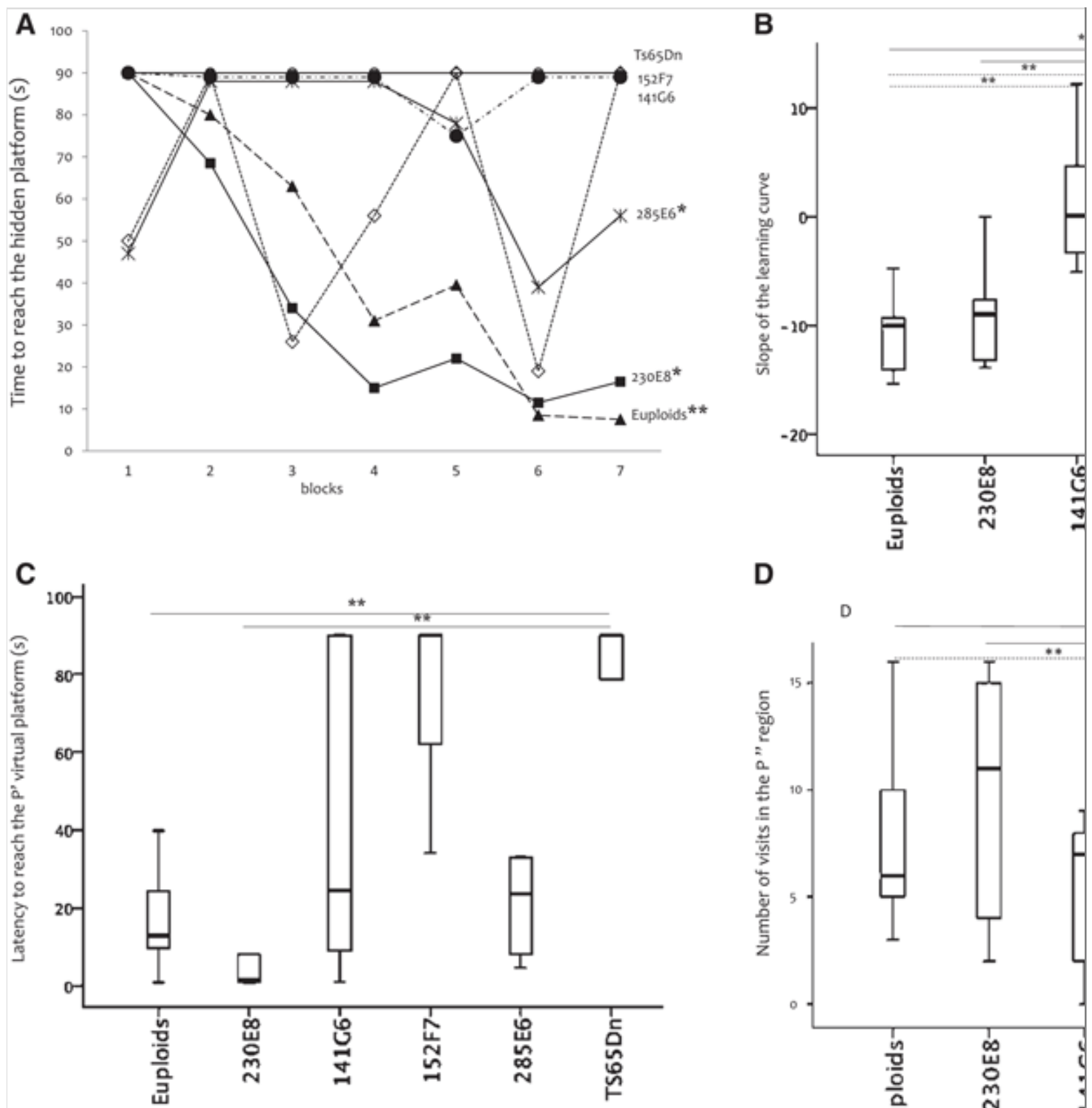

E

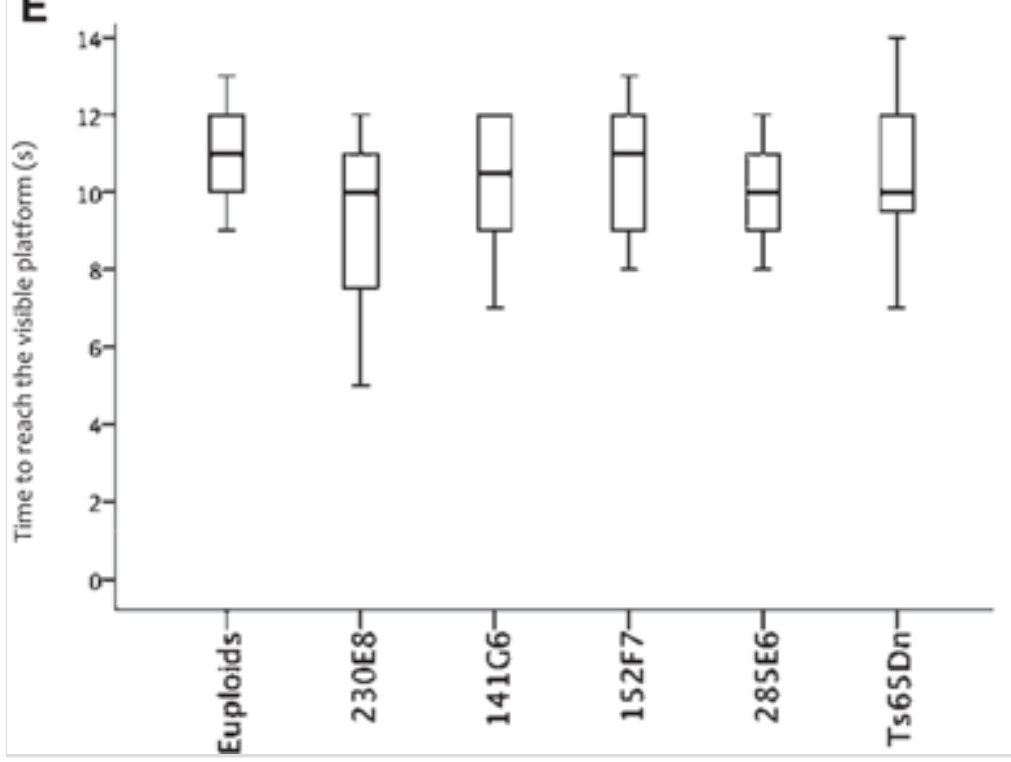

D
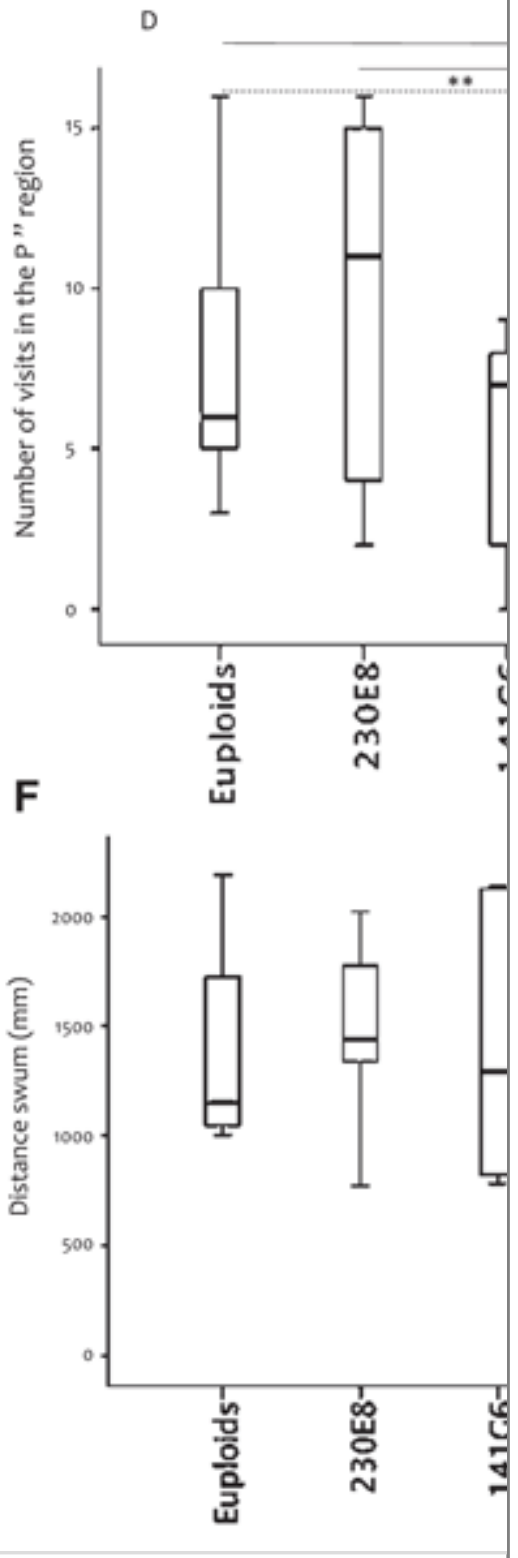


\section{Fig. 4}

Cognitive performance in radial maze $(\mathbf{a}, \mathbf{b}, \mathbf{c})$. a Number of errors in RAM from day 1 to day 5. b Slope of the learning curve. $\mathbf{c}$ Total number of errors along the 5 days. Sample size: euploids and 152F7 $\mathrm{n}=10$, and other groups $\mathrm{n}=9$ ). Solid lines: Ts65Dn versus other groups, doted lines: euploid versus other groups. ${ }^{*} p \leq .01,{ }^{*} p \leq .001$ 

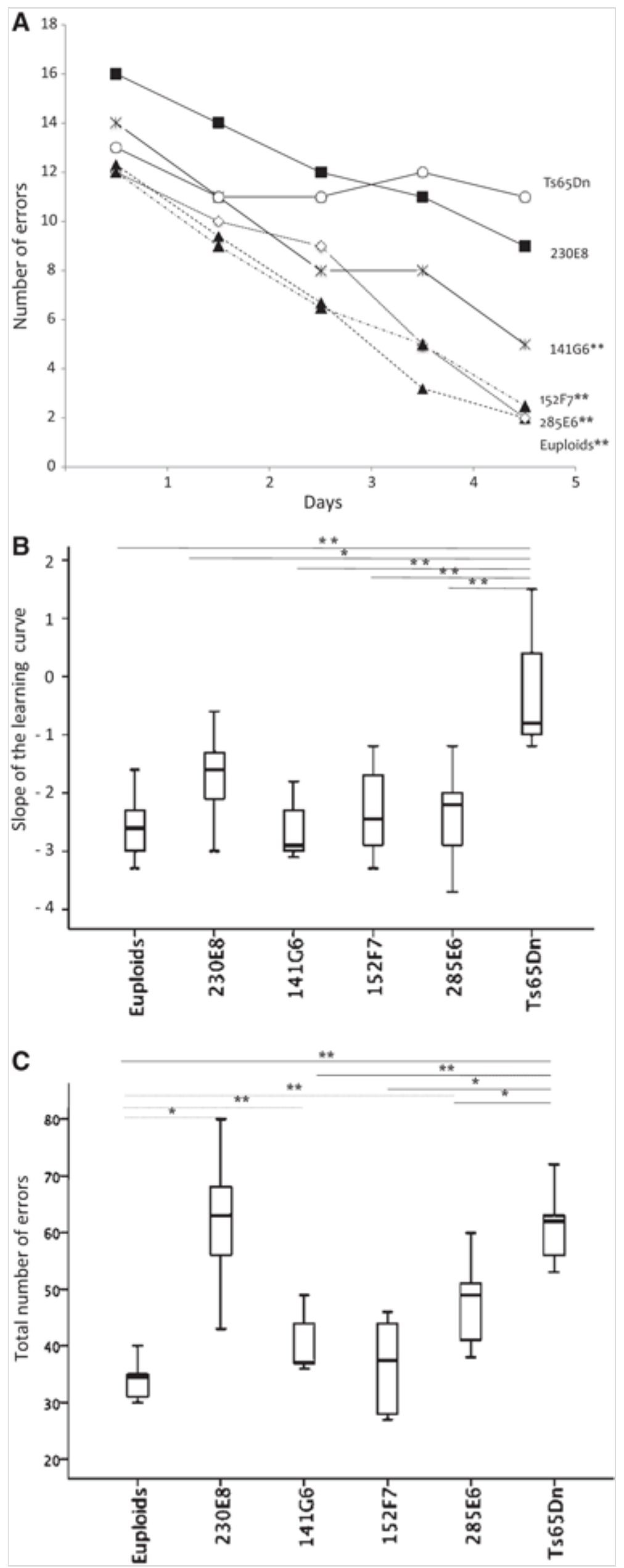


\section{Fig. 5}

Performance in conditioning (a, b). a Associative conditioning in altered context, $\mathbf{b}$ cued associative conditioning. White boxes represent the number of freezing episodes on day 1, striped boxes indicate the number of freezing episodes on day 2. Parentheses indicate the groups for which the median of the difference between score on day 1 and day 2 differ - see text. Ts65Dn $n$ $=9$, other groups $\mathrm{n}=14$.). Solid lines: Ts65Dn versus other groups, doted lines: euploid versus other groups. ${ }^{*} p \leq .01,{ }^{* *} p \leq .001$

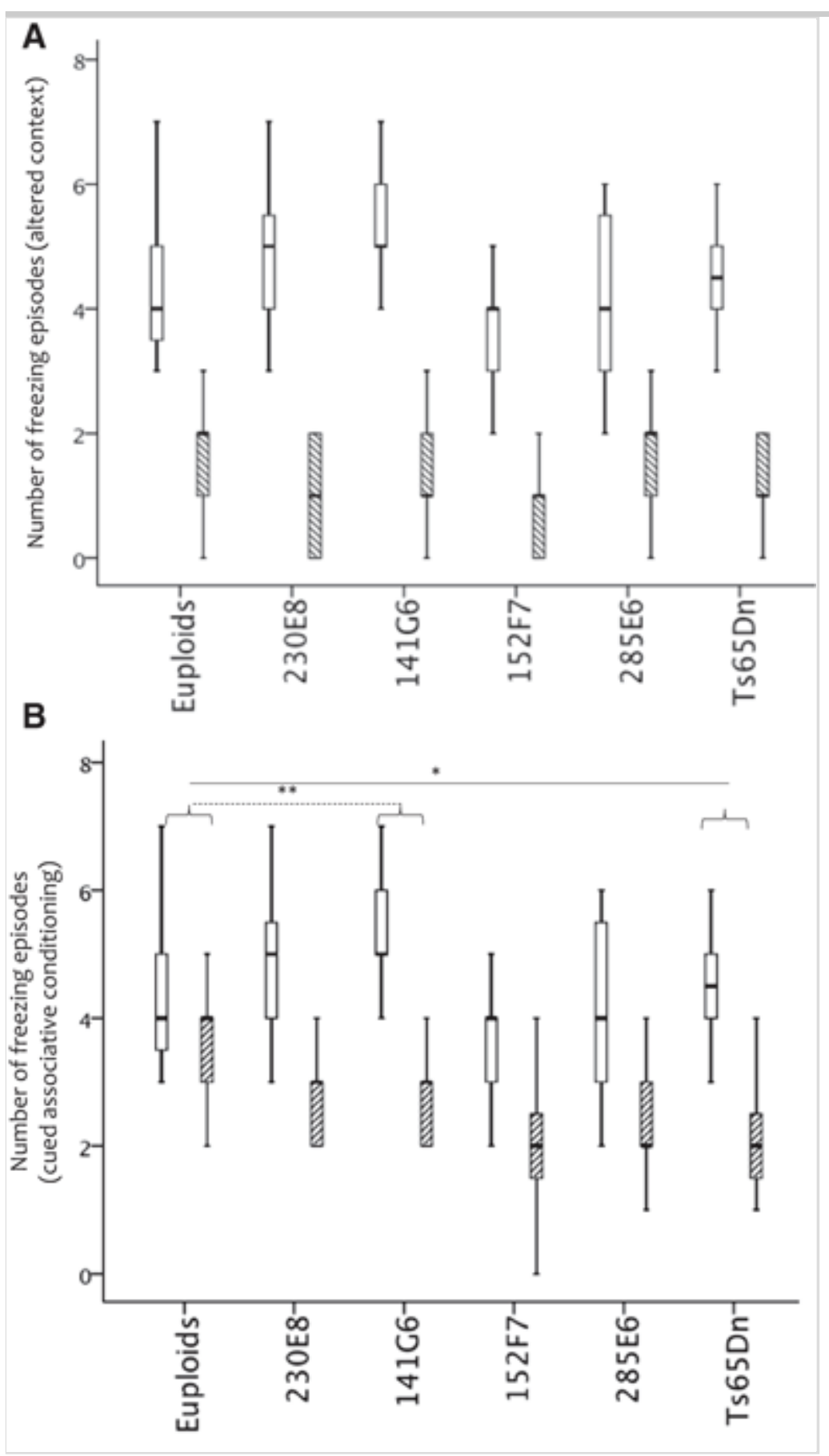




\section{Fig. 6}

Performance in object recognition and exploration tasks (a, b). a Novel object recognition. White box represent the number of contacts towards the familiar object, striped boxes indicate the number of contacts toward a novel object. Parentheses indicate the groups for which the median of the difference between the number of contact towards the familiar and towards the novel objects differ - see text. Sample size euploid $n=12 ; 230 E 8,141 \mathrm{G} 6$ and 152F7 $\mathrm{n}=10,285 \mathrm{E} 6 \mathrm{n}=9$, and Ts65Dn $\mathrm{n}=6$. $\mathbf{b}$ Number of head dipping in the hole-board (Ts65Dn $\mathrm{n}=6$; for other groups $\mathrm{n}=9$ ). Solid lines: Ts65Dn versus other groups, doted lines: euploid versus other groups. ${ }^{*} p \leq .01,{ }^{*} p$ $\leq .001$
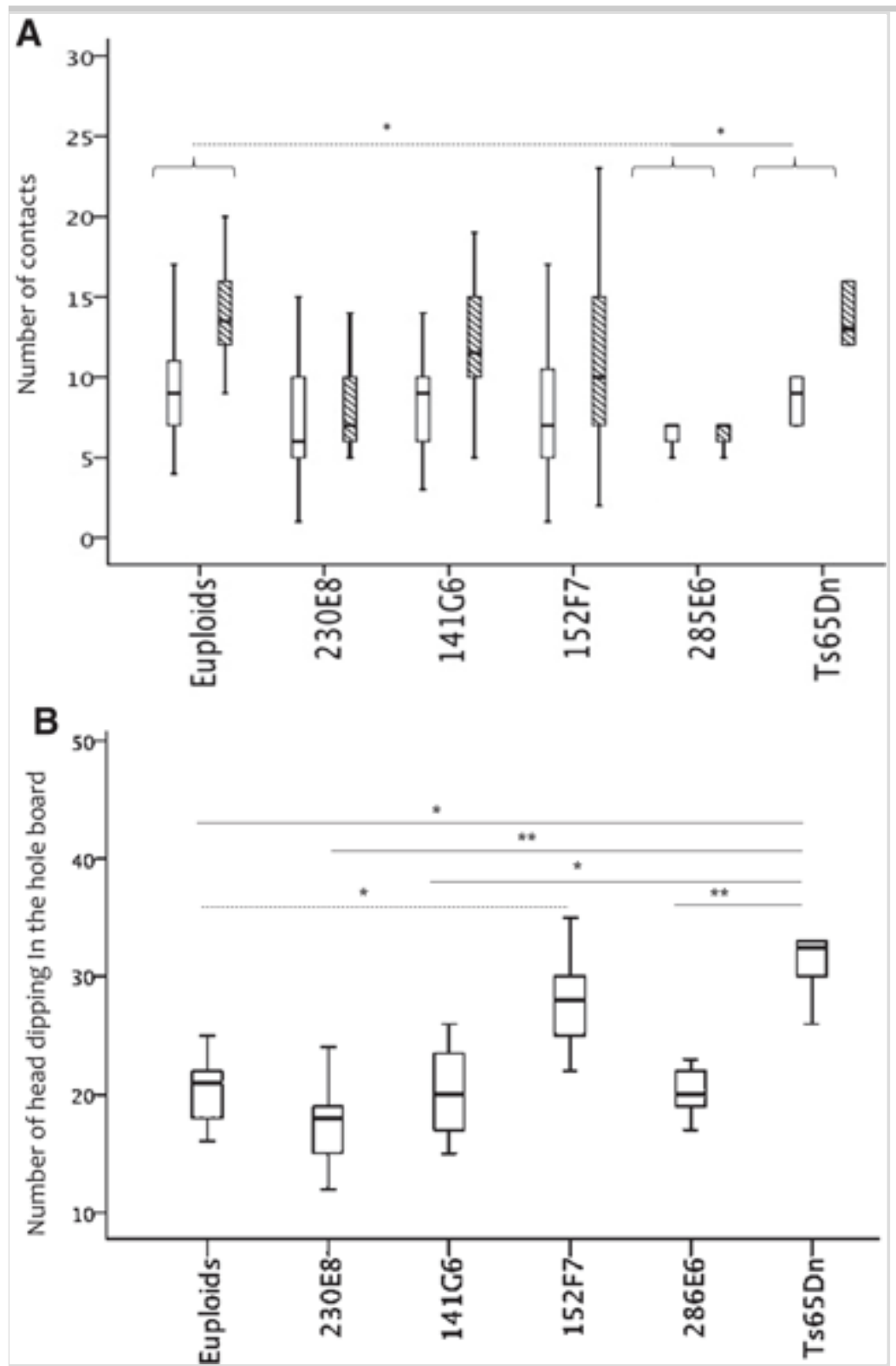


\section{Fig. 7}

Motor performance by segmental trisomic strains of mice $(\mathbf{a}, \mathbf{b}, \mathbf{c})$. a Distance walked over $20 \mathrm{~min}$ in the open-field (sample size: euploid $\mathrm{n}=12$, 230E $8 n=10,141 G 6 n=11,152 F 7 n=11,285 E 6 n=12$ and Ts65Dn $n=6$ ). b Forelimb traction strength measured in gram-force (Ts65Dn, $\mathrm{n}=8$, and for other groups $n=14$ ). $\mathbf{c}$ Number of hind paw slips on a notched bar task ( $n$ as in B). Solid lines: Ts65Dn versus other groups, doted lines: euploid versus other groups. ${ }^{*} p \leq .01,{ }^{* *} p \leq .001$ 

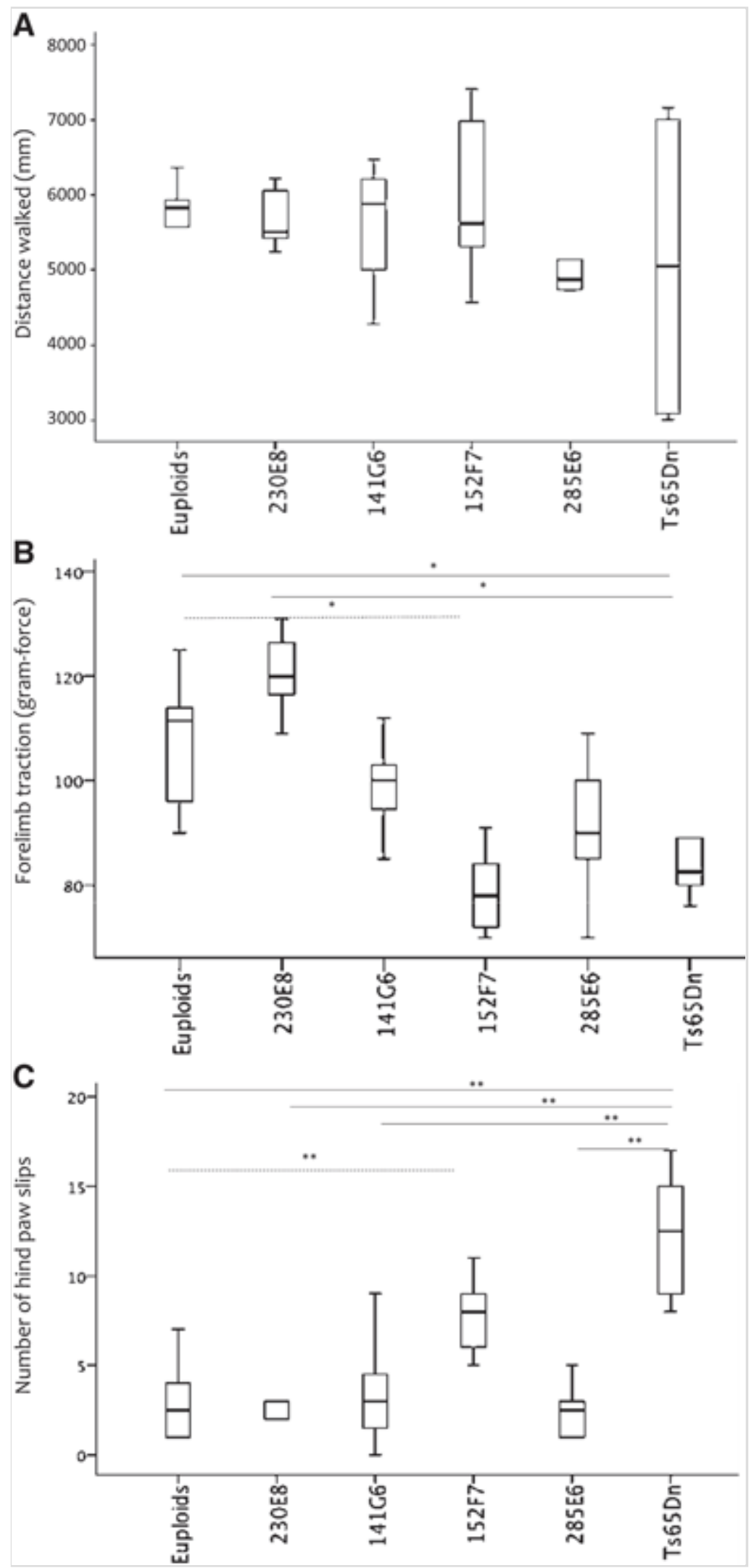

Fig. 8

Cerebrum MRI of segmental trisomic and euploid mice, volumetric analysis (a-f). a Brain volume; b cortex \% (the volume of the structure / volume of the brain); $\mathbf{c}$ hippocampus \%; d striatum \%; e cerebellum \% (the cerebellum 
volume / cerebrum volume); f lateral + third ventricles $\%$. $n=6$ for all groups. Solid lines: Ts65Dn versus other groups, doted lines: euploid versus other groups; ${ }^{*} p \leq .01,{ }^{* *} p \leq .001$

A

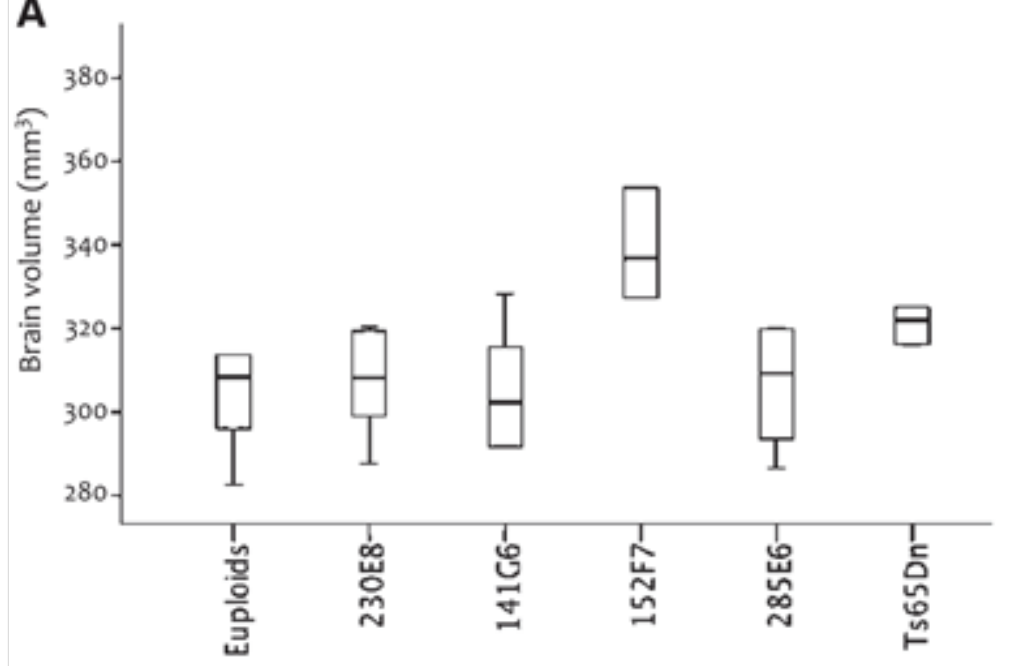

C
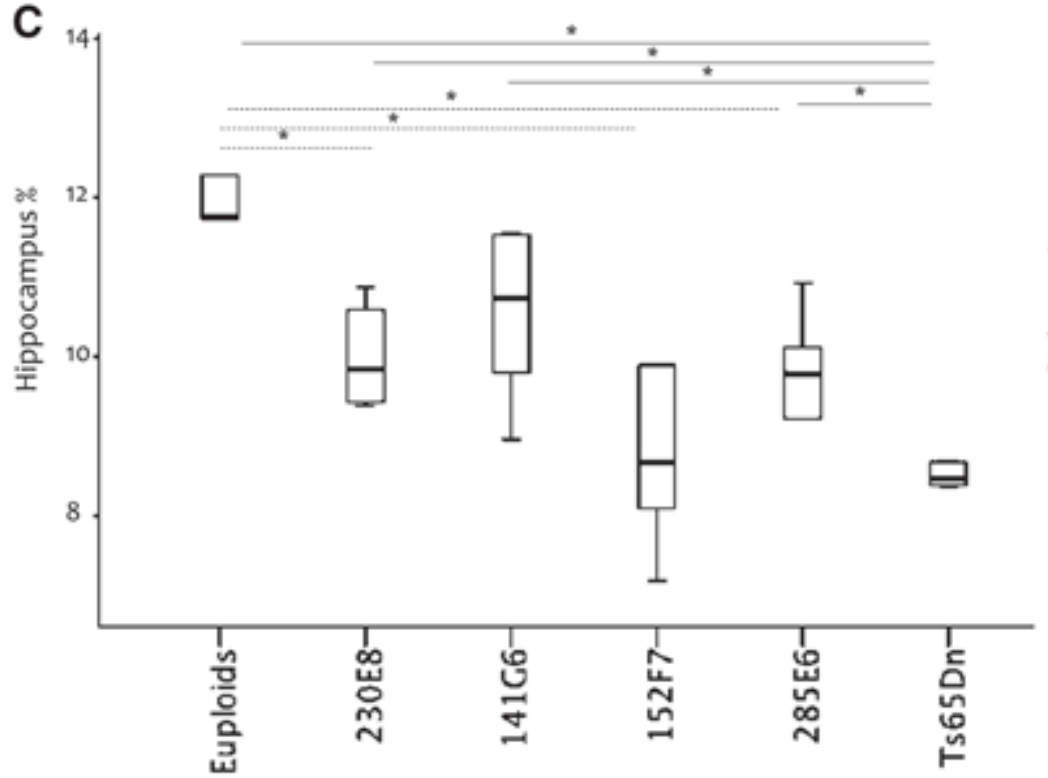

E
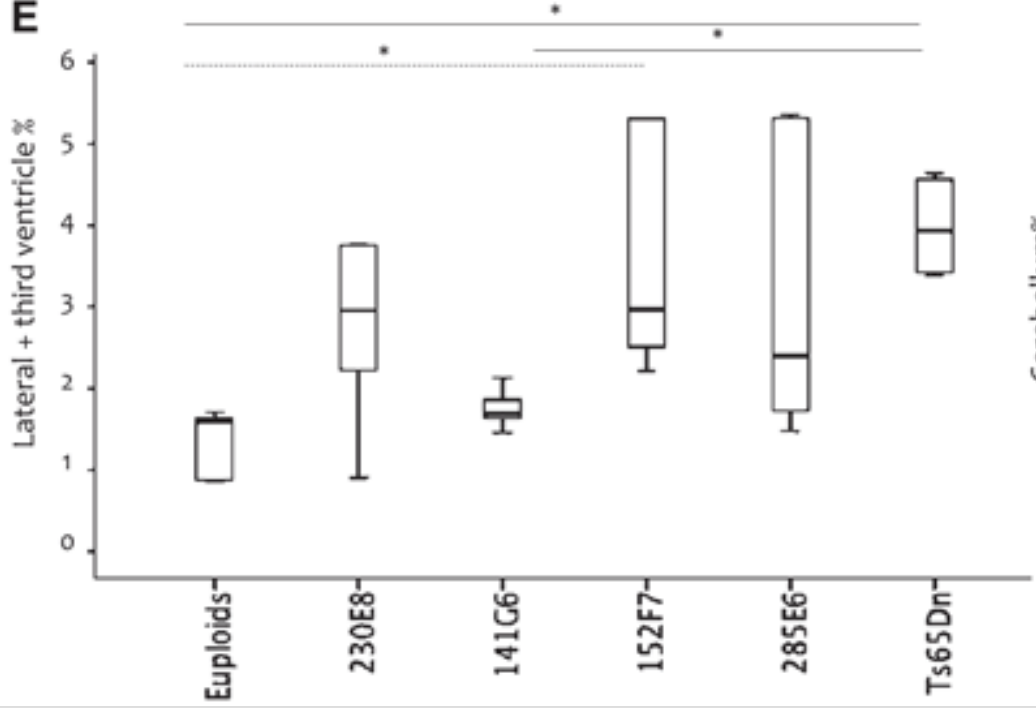
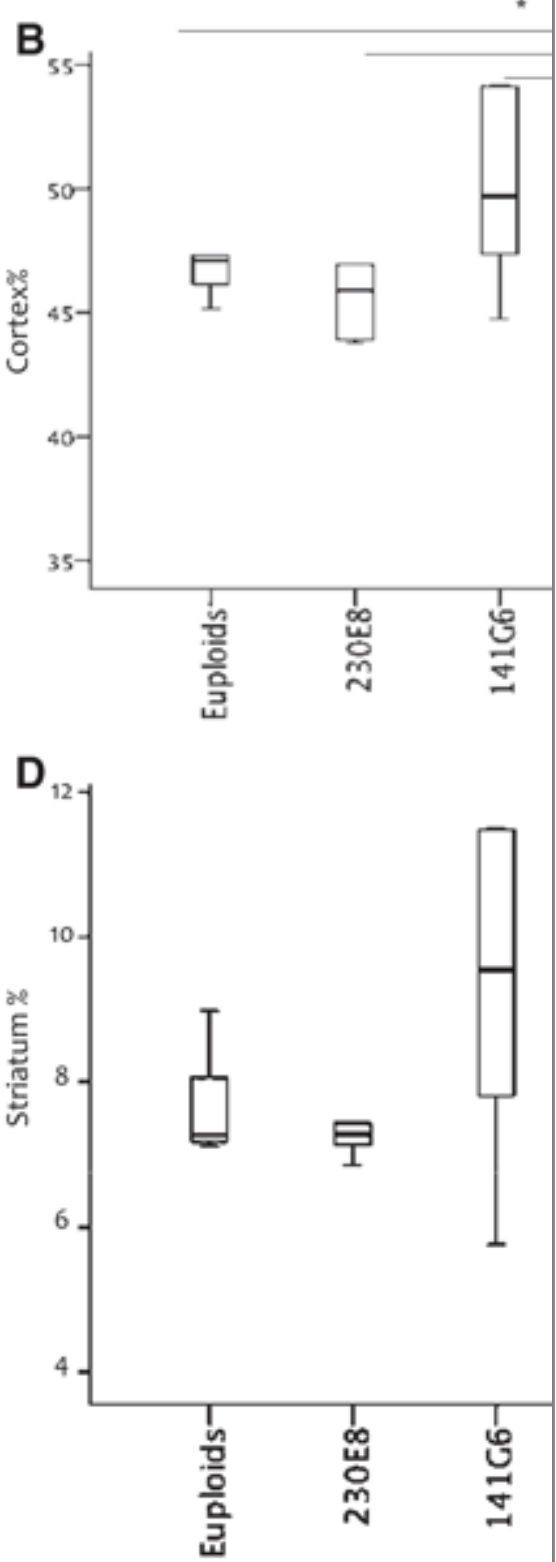

$\mathbf{F}$

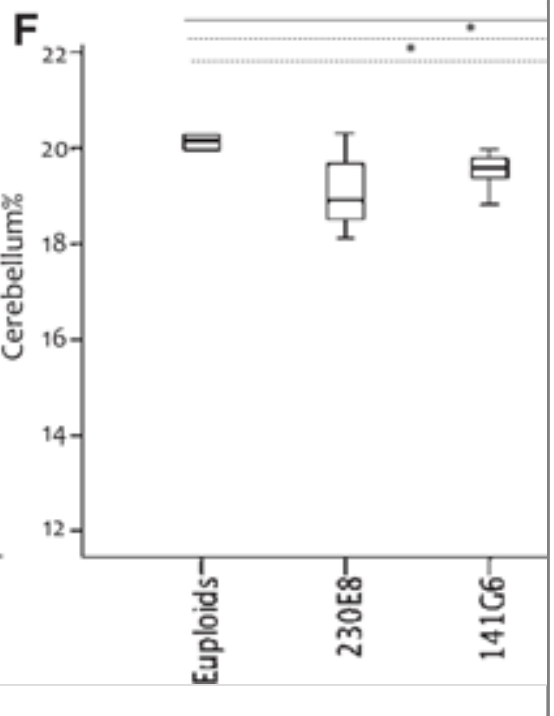




\section{Cognitive performances}

The Ts65Dn group, the euploids and the segmental trisomies covering the D21S17-ETS2 did not suffered from vision, auditory, and pain sensitivity impairment.

Results of the MWM are presented in Fig. 3. We calculated the median time of each strain across the 7 blocks. The six groups (euploids, Ts65Dn and the 5 segmental trisomies covering the D21S17-ETS2 region) recorded different times to reach the hidden platform $\left(\chi^{2}=23.21, \mathrm{df}=5, p<.001\right)$. Only the euploids and the 230E 8 mice fulfilled the learning criterion, i.e. reducing the time needed to reach the platform from one block to the next $\left(\chi^{2}=33.04, \mathrm{df}=6, p<.001\right.$ and $\chi^{2}=21.38, \mathrm{df}=6, \mathrm{p}=.002$, respectively). The 285E6 group had between-block differences but there was no reduction in the time to reach the hidden platform, which is the criterion for learning (Fig. $3 \mathrm{a}$ ). A negative slope of the curve indicates learning. The slopes differed between the 6 strains $\left(\chi^{2}=28.30, \mathrm{df}=5, p<.001\right)$ with steepest negative slope for euploid group - see Fig. $3 \mathrm{~b}$ for partial comparisons and Table 2 for the size of the effects. The slope of the TS65Dn group was null with no variation across blocks and TS65Dn performance was the worst of all the groups. The size of the difference between the euploids and the Ts65Dn was $69 \%$. Performance by the $285 \mathrm{E} 6$ and 141G6 groups was erratic, with good scores for the first block and bad scores for some of the later blocks. Two variables were measured in the probe test: (1) latency to reach the P' virtual platform, which differentiated the 6 groups $\left(\chi^{2}=16.62, \mathrm{df}=5, p=.005\right.$; Fig. $\left.3 \mathrm{c}\right)$, and (2) the number of visits in $\mathrm{P}^{\prime}$ that includes visits in $\mathrm{P}^{\prime}\left(\chi^{2}=26.18, \mathrm{df}=5, p<.001\right.$; Fig. $\left.3 \mathrm{~d}\right)$. Compare to TsD65Dn, the euploids showed a shorter latency to reach $\mathrm{P}$ ' and a higher number of visits in P" (effect sizes 48 and 53\%, respectively). We controlled that time to reach the visible platform (Fig. $3 \mathrm{e}$ ) and the distance swum (Fig. 3 f) did not differed between the six groups.

For the RAM, the number of errors decreased significantly from day 1 to day 5 in each strain except for Ts65Dn (Fig. 4 a). The slopes of the learning curve differed between the six groups $\left(\chi^{2}=26.31, \mathrm{df}=5, p<.001\right)$ - see Fig. $4 \mathrm{~b}$ for partial comparisons and Table 2. The strains differed when the number of errors along the 5 days was analyzed $\left(\chi^{2}=40.77, \mathrm{df}=\right.$ $5, p<.001)-$ Fig. $4 \mathrm{c}$ for partial analyses. The size of the difference between the best learner (euploid group) and the poorest (Ts65Dn) reached 
$71 \%$ (Table 2). The number of errors was higher for the 230E8 strain than for the euploids whereas the slope of the learning curve did not differed between the two groups (Fig. $4 \mathrm{~b}$ and c, and Table 2). Two conditions were observed with the "fear conditioning" task. The altered context score did not show a significant strain difference between the 6 strains whereas the cued conditioning score differed $\left(\chi^{2}=15.24, \mathrm{df}=5, \mathrm{p}=.01\right.$ ) (Fig. $5 \mathrm{a}$, b; Table 2). No significant difference between the 6 strains was observed with novel object recognition with a significant lower score for 285E6 compared to euploid and Ts65Dn (Fig. 6a) Engr the hole-board, the repetitive head dipping was very scarce ancuid not differ between the groups. Figure $6 \mathrm{~b}$ represents the number of non-repetitive head dipping. The 6 strains differed $\left(\chi^{2}=28.60, \mathrm{df}=5, p<.001\right)$.

\section{Motor performance}

In the open-field test, the ambulation (total distance walked in $\mathrm{mm}$, Fig. $7 \mathrm{a}$ ), the number of entrances into the central area and other behavioral parameters (leaning, rearing and grooming - data not shown) did not differentiate the strains. The inactivity periods were similar for all the strains (from 310 to 317). Leaning takes most of the activity of the mice but without difference between strains.

Specific deficits were found in forelimb traction strength and in hind paw coordination. Forelimb traction strength presented differences between the euploid group and the trisomic groups $\left(\chi^{2}=28.49, \mathrm{df}=5, p<.001\right)$; see Fig. $7 \mathrm{~b}$ and Table 2. Number of hind paw slips differed between the euploid and the segmental trisomics $\left(\chi^{2}=28.75, \mathrm{df}=5, p<.001\right.$; Fig. $7 \mathrm{c}$; Table 2).

\section{Brain structure: solumetric analysis}

The volume of individual structures was expressed as a percentage of total brain volume because brain volume (Fig. 8 a) differentiated the 6 groups $\left(\chi^{2}=16.95, \mathrm{df}=5, p=.005\right)$. Although none of the partial comparison was significant, the sizes of the difference between euploids and Ts65Dn and $152 \mathrm{~F} 7$ were in the mild range ( 30 and $42 \%$ respectively). Cortex $\%$ (Fig. 8 b; Table 2) differed across the strains $\left(\chi^{2}=18.60, \mathrm{df}=5, p=.002\right)$. Five partial comparisons reached the 0.01 threshold with Ts65Dn. The difference between euploids and 285E6 was not significant but the size of the difference was in the mild range with a lower $\%$ of cortex for the 
euploids. The hippocampus $\%$ differed $\left(\chi^{2}=24.56, \mathrm{df}=5, p<.001\right)$

(Fig. 8c; Table 2). There was no difference for the striatum \% (Fig. $8 \mathrm{~d}$; Table 2). The ventricle $\%$ differed $\left(\chi^{2}=19.40, \mathrm{df}=5, p=.002\right.$ ) (Fig. $8 \mathrm{e}$;

Table 2$)$. The volume of the cerebellum was expressed as a percentage of the whole cerebrum, and differed across the groups $\left(\chi^{2}=16.04, \mathrm{df}=5, p=\right.$ .007) (Fig. 8f; Table 2).

\section{Discussion}

Several regions syntenic to HAS 21 modulate brain and cognition when they are triplicated in segmental mouse models of TRS21. But we still ignore whether the triple copy of a syntenic HSA21 fragment impacts globally the cognitive functions or impacts only specific functions. We addressed the question by selecting a sample of tasks in line with the cognitive framework of Milner, Squire and Kandel (Milner et al. 1998), and measured brain structures known to be modified in TRS21 patients. We also ignore whether the phenotypic modification induced by a segmental mouse trisomy reported only a significant difference or a pathological variation. We selected the effect size (Cohen 1988) to express between-group differences and with $\mathrm{R}^{2}=0.30$ (or $30 \%$ of variance) for mild impairment, and $\mathrm{R}^{2}=0.50$ (or $50 \%$ of variance) for impairment. Our expectation was that the largest effect sizes would be observed when euploid and Ts65Dn groups were compared. The effect sizes of comparisons of the D21S17-ETS2 extra fragment groups and euploid groups would then provide information on the impact which certain parts of HSA21 would have on the brain and behavior of persons with the $\operatorname{Trs} 21$ phenotype.

It has been argued that comparisons of Ts65Dn and subjects with extra fragments encompassed in the D21S17-ETS2 is a source of a bias as Ts65Dn not only has a triple copy of an MMU16 fragment that is syntenic to HSA21, but also carries a non-syntenic MMU17 fragment (Yu et al. 2010a, b). The non-syntenic MMU17 fragment is located between App and Cdarx, in the centromeric part of Ts65Dn. The non-syntenic MMU17 fragment is encompassed by Ms1Ts65 which is produced by splitting Ts65Dn at the Sod1 locus (see Fig. 1 c), but Ms1Ts65 is not involved in cognitive disorders - see (Seregaza et al. 2006) for a review-which means that the MMU17 non-syntenic fragment cannot be associated with the cognitive impairment observed in Ts65Dn. 


\section{Heterogeneity of cognitive and motor abilities and of brain structures in the Ts65Dn mouse}

The heterogeneity of cognitive profiles that characterizes TRS21 patients is found in Ts65Dn mice since the pioneering studies (Escorihuela et al. 1995, 1998; Reeves et al. 1995). In reviews (Roubertoux and Carlier 2010; Seregaza et al. 2006) we noted that poor performance by Ts65Dn mice was reported in 8 out of 11 studies of spatial memory, 7 out of 8 studies of discriminative memory and 2 out of 3 studies of long-term memory when the differences were expressed as inferential statistics. Similar results were found in the present study, but results expressed as effect size cast a different light on the conclusions (Table 2). For effect size, 18 traits were measured; eleven were found to be impaired, and two mildly impaired. Impairment was observed with reference memory, working memory and exploratory behavior, but no impairment was found on episodic memory, associative memory or discriminative memory. The exploration score is notably high in Ts65Dn as previously demonstrated (Escorihuela et al. 1995) and could be an indicator of the hyperactivity associated with attention deficits. Our results do not support a stereotypy hypothesis.

The gait and movements of persons with TRS2 1 are characterized by impaired motor efficiency or clumsiness (Galli et al. 2013; Jover et al. 2010; Palisano et al. 2001; Rigoldi et al. 2009; Vicari 2006), and to such an extent that it has been included in the Jackson signs for the TRS21 phenotype. More interestingly, motor exercise interacts with cognitive function in Ts65Dn mice (Kida et al. 2013). Impaired tonicity has been reported in children with TRS21 (Uyanik et al. 2003) as poor limb coordination. Ts65Dn mice displayed impaired tonicity and hind limb coordination (effect size 55\% and 67\%, respectively, see Table 2; Fig. 7 b, c). In the MWM, swimming differences did not impact the learning performance: trisomic mice reached the visible platform as quickly as the euploids (Fig. 3 e).

The total volume of the brain and the volume of most brain structures were found to be smaller in TRS2 1 patients, the largest difference being for the hippocampus ( -43 to $-50 \%)$, followed by the cerebellum $(-24 \%)$, and the cortex (-17\%) (Roubertoux and Carlier 2009) Fig. 12.1, p 17. The size of the decrease in volume is predictive of cognitive and brain impairments in 
both humans (Allin et al. 2001; Peng et al. 2015) and rodents (Caston et al. 2004; Colombel et al. 2004; Goddyn et al. 2006; Rosin et al. 2015; Siraly et al. 2015). Smaller brain volumes are also found in Ts65Dn mice when compared to euploids, with large effect sizes for the hippocampus, the cortex and the cerebellum (69\%, 69\% and 0.61, respectively).

\section{Comparison of phenotypes: segmental trisomic fragments in the D21S17-ETS2 region and Ts65Dn}

The 152F7 fragment has been proposed to model characteristics of the cognitive impairment observed in TRS21 (Smith et al. 1997). Our study can confirm that the fragment is similar to Ts65Dn for reference memory (learning slope and probe test in the MWM) and exploration, but not for working memory (RAM); and the triple copy of the 152F7 fragment does not affect other forms of memory. For motor behavior, the effect sizes match Ts65Dn. The size of the cortex is not impacted in $152 \mathrm{~F} 7$.

In comparisons with euploids, the triple copy of the 230E8 fragment shows an impairment of the volume of the hippocampus and of number of errors in RAM, and shows mild impairment in size of ventricles. The 141G6 mice range from mildly impaired to impaired for cognition (slope of learning curve in MWM, and in RAM, altered context conditioning) and for the anatomy of the brain (smaller hippocampus and larger ventricles).

The 285E6 strain contains only the Kcnj6 also named Girk2 gene. Kcnj6 plays a crucial role in postsynaptic mechanisms because its channels are coupled with alpha-adrenergic, muscarinic cholinergic and cannabinoid receptors but also with gamma-aminobutyric acid B receptors (Blednov et al. 2003 ) that modulates the synaptic transmission in TRS21 mouse models (Kleschevnikov et al. 2012). Our results are in agreement with recent studies showing that a triple copy of Kcnj6 impairs brain and behavioral traits (Cooper et al. 2012; Jiang et al. 2015) but the present results demonstrate that the cognitive impairment is mild. The 285E6 mice are mildly impaired for the novel object recognition task. Motor characteristics (distance walked and tonicity) were subjected to a mild impairment. The hippocampus and cerebellum are substantially smaller (effect size 62\%), and the ventricles are larger (effect size 42\%, Table 2).

Our findings confirm that the profile of Ts65Dn is closer to the profile of 
152F7, than to the other fragments in the D21S17-ETS2 region, for reference memory, confirming the role of Dyrkla. The role of this gene should not be generalized. The 152F7 fragment is not implicated in several other cognitive processes: working, discriminant and episodic memory.

\section{Epistatic effects between chromosomal regions}

A number of studies have reported interactions between genes or chromosomal fragments syntenic to HSA21 (Jiang et al. 2015; Zhang et al. 2014). Proteins encoded by genes located on fragments in the D21S17-ETS2 region interact (Fig. 2b), suggesting there are epistatic effects between the chromosomal fragments. We detected three interactions between isolated fragments and Ts65Dn. An interaction can produce an $\mathrm{R}^{2}$ value that is higher for the triple copy of the fragment than the $\mathrm{R}^{2}$ for Ts65Dn. The first interaction was observed for the number of visits in the $\mathrm{P}$ " region. The size of the effect is higher for 152F7 than for Ts65Dn (69\% vs. $53 \%$ ). The second was for discriminative memory (altered context associative conditioning) showing mild impairment for 141G6 compared to euploids, but the effect was not observed when the fragment was inserted into Ts65Dn. The third is the distance walked, showing mild impairment for 285E6 compared to euploids; however, in the comparison of Ts65Dn and euploids, the size of the effect is close to zero.

\section{The hippocampus hypothesis}

After Pennington's seminal paper (Pennington et al. 2003 )we have seen arguments on the role of the hippocampus in cognitive dysfunction in patients with TRS21 (Menghini et al. 2011) as well as in mouse models (Smith et al. 1997; Yu et al. 2010b). Our findings confirm the hypothesis but cast a different light on conclusions drawn. Nine of the genes mapped on the fragments covering the D21S17-ETS2 region are over transcribed in the hippocampus, and all nine genes are found in each of the four strains. The hippocampus is smaller in size in the four strains compared to euploid mice, and, together with the larger ventricles, is one of two invariant features of TRS21. In our TRS21 models, the difference in the size of the hippocampus is not proportional to the degree of impairment of cognitive and motor skills. Cerebellum proportion may be seen as relevant for a number of reasons. First, it is in the pathological range of variations for all the strains except for 230E8. Many studies have presented evidence 
showing that small volume of the cerebellum modifies reference memory processes (as measured in the MWM), and that a smaller hippocampus alters associative memory (fepddyn et al. 2006). While there is no direct anatomical pathway between the hippocampus and the cerebellum, there are functional links between the two organs, and theta oscillations can contribute to such functional links. During associative conditioning theta oscillations occur in the cerebellum and also in the hippocampus, and are synchronized in both organs (Nokia and Wikgren 2010; Wikgren et al. 2010). And the cortex contributes to the regulation of the interaction between the hippocampus and the cerebellum. An abnormally small cortex may cause selective disorganization of the interaction process between the hippocampus and the cerebellum (Weiss and Disterhoft 2011) but the hippocampal - cerebellar impairment appears as a common characteristic of the Ts65Dn and of three of the strains belonging to D21S17-ETS2 region (141G6, 152F7 and 285E6) but not of 230E8.

\section{General conclusion}

Using four chromosomal fragments covering the D21S17-ETS2 region, we found that the triple copy of the fragments does not impair the same functions and the same brain structures. The profile of $152 \mathrm{~F} 7$ that carries the DYRK1A gene is more affected and closer than TS65Dn but the three other strains are also impaired even though in a lesser extent. The hippocampus-cerebellum interaction mechanism is associated with the impairment of Ts65Dn and of 141G6, 152F7 and 285E6 that it encompasses whereas a hippocampus mechanism only could be associated with 230E8 impairment. The results emphasize the necessity to use an exhaustive and standardized battery of cognitive and motor tasks for the exploration of segmental mouse models. It is unwise to claim that a trisomic strain of mouse or any mouse model of ID, exhibits cognitive impairment when it was subjected to only one learning test. It may be unwise even more to accept that a non-human organism is a model of trisomy 21 or of another disorder without considering the effect size of the difference between mutants and controls.

\section{Acknowledgements}

We thank INSERM U 910 "Génétique Médicale, Génomique Fonctionnelle”, CNRS UMR 7290 Psychologie cognitive, Fédération de 
Recherche 3C-Comportement Cerveau-Cognition, and Aix Marseille University, and also the Fondation Jérôme Lejeune. AFI-Aveyron provided invaluable assistance with computer software for the MWM analysis and the Cavalieri stereology method. We wish to express our gratitude to the European Mouse Mutant Archive (EMMA) for the generous gift of two strains of segmental trisomic mice. Maire-Laure Dessain (UPS 44 TAAM, CNRS) genotyped the mice. Our special thanks to the anonymous reviewers of the first version of the manuscript and to Doctor Henri Bléhaut for his scientific support.

Author contributions Conceived and designed the experiments: P-L Roubertoux, M. Carlier, S. Tordjman. Behavioral assessment of the mice: P-L Roubertoux, A. Ghata, C. Bartoli, M. Carlier. MRI: N Baril. P. Cau, P-L. Roubertoux. Data analysis : P-L Roubertoux, M Carlier. Molecular analysis: J. di Christofaro, P Bourgeois, P-L Roubertoux. Mouse breeding: C. Scajola. Wrote the paper: P-L Roubertoux, M Carlier. All the authors reviewed the manuscript for intellectual content and approved submission.

\section{Compliance with Ethical Standards}

Conflict of interest Pierre L. Roubertoux, Nathalie Baril, Pierre Cau, Christophe Scajola, Adeline Ghata, Catherine Bartoli, Patrice Bourgeois, Julie di Christofaro, Sylvie Tordjman, Michèle Carlier declare that they have no conflict of interests.

Ethical approval The protocols for the present study were approved by the Comité d'éthique pour l'expérimentation animale $\mathrm{n}^{\circ} 14$, under the title "Rôle de la région D21517-ET52 (MMU 16) dans les dysfonctions cérébrales de souris modèles du syndrome de Down," with PL Roubertoux as the main investigator (reference number 23-23092012, dated October 11, 2012).

\section{References}

Allin M, Matsumoto H, Santhouse AM, Nosarti C, AlAsady MH, Stewart AL, Rifkin L, Murray RM (2001) Cognitive and motor function and the size of the cerebellum in adolescents born very pre-term. Brain $124: 60-66$ 
Antonarakis SE, Lyle R, Dermitzakis ET, Reymond A, Deutsch S (2004) Chromosome 21 and down syndrome: from genomics to pathophysiology. Nat Rev Genet 5:725-738

Arenas M.C., Daza-Losada M., Vidal-Infer A., Aguilar M.A., Minarro J., Rodriguez-Arias M. (2014). Capacity of novelty-induced locomotor activity and the hole-board test to predict sensitivity to the conditioned rewarding effects of cocaine. Physiol Behav 133, 152-160.

Belichenko NP, Belichenko PV, Kleschevnikov AM, Salehi A, Reeves RH, Mobley WC (2009) The "Down syndrome critical region" is sufficient in the mouse model to confer behavioral, neurophysiological, and synaptic phenotypes characteristic of Down syndrome. J neurosci 29:5938-5948

Blednov YA, Stoffel M, Alva H, Harris RA (2003) A pervasive mechanism for analgesia: activation of GIRK2 channels. Proc Natl Acad Sci USA 100:277-282

Boker LK, Blumstein T, Sadetzki S, Luxenburg O, Litvak I, Akstein E, Modan B (2001). Incidence of leukemia and other cancers in Down syndrome subjects in Israel. Int J Cancer 93, 741-744.

Bourgeois P, Roubertoux PL (2015) Finding endophenotypes for autism spectrum disorders (ASD): cDNA microarrays and brain transcripts. In: Neuromethods, Roubertoux PL (eds) Organism models of autism spectrum disorders. Springer, New York, pp 217-238

Breia P, Mendes R, Silvestre A, Goncalves MJ, Figueira MJ, Bispo R (2014) Adults with Down syndrome: characterization of a Portuguese sample. Acta Med Port 27:357-363

Carlier M, Roubertoux PL (2014) Genetic and environmental influences on intellectual disability in childhood. In: Finkel D. and Reynold C.A. (eds) Behavior genetics of cognition across the lifespan Springer, New york, pp 69-101

Carlier M, Desplanches AG, Philip N, Stefanini S, Vicari S, Volterra V, Deruelle C, Fisch G, Doyen AL, Swillen A (2011) Laterality preference 
and cognition: cross-syndrome comparison of patients with trisomy 21 (Down), de17q11.23 (Williams-Beuren) and del22q11.2 (DiGeorge or Velo-Cardio-Facial) syndromes. Behav Genet 41:413-422

Carr J (2012) Six weeks to 45 years: a longitudinal study of a population with Down syndrome. J Appl Res Intellect Disabil 25:414-422

Caston J, Chianale C, Mariani J (2004) Spatial memory of heterozygous staggerer $(\operatorname{Rora}(+) / \operatorname{Rora}(\mathrm{sg}))$ versus normal $(\operatorname{Rora}(+) / \operatorname{Rora}(+))$ mice during aging. Behav Genet 34:319-324

Caubit X, Gubellini P, Andrieux J, Roubertoux PL, Metwaly M, Jacq B, Fatmi A, Had-Aissouni L, Kwan KY, Salin P et al. (2016). TSHZ3 deletion causes an autism syndrome and defects in cortical projection neurons. Nat Genet

Chabert C, Jamon M, Cherfouh A, Duquenne V, Smith DJ, Rubin E, Roubertoux PL (2004) Functional analysis of genes implicated in Down syndrome: 1. Cognitive abilities in mice transpolygenic for Down Syndrome Chromosomal Region-1 (DCR-1). Behav Genet 34:559-569

Chapman RS, Hesketh LJ (2001) Language, cognition, and short-term memory in individuals with Down syndrome. Down's Syndr Res Pract $7: 1-7$

Cohen J (1988) Statistical power analysis for the behavioral sciences. Lawrence Earlbaum Associates., Hillsdale, NJ

Colombel C, Lalonde R, Caston J (2004) The effects of unilateral removal of the cerebellar hemispheres on spatial learning and memory in rats. Brain Res 1004:108-115

Contarino A., Baca L., Kennelly A., Gold L.H. (2002). Automated assessment of conditioning parameters for context and cued fear in mice. Learning \& memory 9, 89-96.

Cooper A, Grigoryan G, Guy-David L, Tsoory MM, Chen A, Reuveny E (2012) Trisomy of the G protein-coupled K + channel gene, Kcnj6, 
affects reward mechanisms, cognitive functions, and synaptic plasticity in mice. Proc Natl Acad Sci USA 109:2642-2647

Costanzo F, Varuzza C, Menghini D, Addona F, Gianesini T, Vicari S (2013) Executive functions in intellectual disabilities: a comparison between Williams syndrome and Down syndrome. Res Dev Disabil $34: 1770-1780$

Coussons-Read ME, Crnic LS (1996) Behavioral assessment of the Ts65Dn mouse, a model for Down syndrome: altered behavior in the elevated plus maze and open field. Behav Genet 26:7-13

Couzens D., Cuskelly M., Haynes M. (2011). Cognitive development and Down syndrome: age-related change on the Stanford-Binet test (fourth edition). Am J Intellect Dev Disabil 116: 181-204.

Davisson MT, Schmidt C, Akeson EC (1990). Segmental trisomy of murine chromosome 16: a new model system for studying Down syndrome. Prog Clin Biol Res 360: 263-280.

Delabar JM, Theophile D, Rahmani Z, Chettouh Z, Blouin JL, Prieur M, Noel B, Sinet PM (1993). Molecular mapping of twenty-four features of Down syndrome on chromosome 21. Eur J Human Genet 1:114-124.

Denenberg VH (1969) Open-field bheavior in the rat: what does it mean? Ann N Y Acad Sci 159:852-859

Ennaceur A, Delacour J (1988) A new one-trial test for neurobiological studies of memory in rats. 1: Behavioral data. Behav Brain Res $31: 47-59$

Escorihuela RM, Fernandez-Teruel A, Vallina IF, Baamonde C, Lumbreras MA, Dierssen M, Tobena A, Florez J (1995). A behavioral assessment of Ts65Dn mice: a putative Down syndrome model.

Neurosci Lett 199:143-146

Escorihuela RM, Vallina IF, Martinez-Cue C, Baamonde C, Dierssen M, Tobena A, Florez J, Fernandez-Teruel A (1998). Impaired short- and long-term memory in Ts65Dn mice, a model for Down syndrome. 


\section{Neurosci Lett 247:171-174}

Field A (2005) Discovering statistics using SPSS. SAGE, London

Galli M, Cimolin V, Ferrario D, Patti P, Heaney G, Freedland R, Albertini G, Brown WT (2013). Quantitative 3D evaluation of step ascent and descent in individuals with Down syndrome-analysis of a daily challenging task. J Intellect Disabil Res 57:1143-1151

Ginsburg BE A, WC (1942) Some effects on conditioning on social dominance and subordination in inbred strains of mice. Physiol Zool $15: 485-506$

Goddyn H, Leo S, Meert T, D’Hooge R (2006) Differences in behavioural test battery performance between mice with hippocampal and cerebellar lesions. Behav Brain Res 173:138-147

Grieco J, Pulsifer M, Seligsohn K, Skotko B, Schwartz A (2015). Down syndrome: Cognitive and behavioral functioning across the lifespan. Am J Med Genet Part C 169:135-149.

Hattori M, Fujiyama A, Taylor TD, Watanabe H, Yada T, Park HS, Toyoda A, Ishii K, Totoki Y, Choi DK et al (2000) The DNA sequence of human chromosome 21. Nature 405:311-319

Higurashi M, Oda M, Iijima K, Iijima S, Takeshita T, Watanabe N, Yoneyama K (1990) Livebirth prevalence and follow-up of malformation syndromes in 27,472 newborns. Brain development $12: 770-773$

Hodges H (1996). Maze procedures: the radial-arm and water maze compared. Brain Res Cognit Brain Res 3:167-181.

Irie F, Badie-Mahdavi H, Yamaguchi Y (2012) Autism-like sociocommunicative deficits and stereotypies in mice lacking heparan sulfate. Proc Natl Acad Sci USA 109:5052-5056

Jackson JF, North ER, 3rd, Thomas JG (1976). Clinical diagnosis of Down's syndrome. Clin Genet 9:483-487. 
Janzen LA, David D, Walker D, Hitzler J, Zupanec S, Jones H, Spiegler BJ (2015). Pre-Morbid developmental vulnerabilities in children with newly diagnosed acute lymphoblastic leukemia (ALL). Pediatr Blood Cancer 62:2183-2188.

Jiang X, Liu C, Yu T, Zhang L, Meng K, Xing Z, Belichenko PV, Kleschevnikov AM, Pao A, Peresie J, et al. (2015). Genetic dissection of the Down syndrome critical region. Human Mol Genet 24:6540-6551.

Jover M, Ayoun C, Berton C, Carlier M (2010). Specific grasp characteristics of children with trisomy 21. Dev Psychobiol 52:782-793.

Kafkafi N, Lipkind D, Benjamini Y, Mayo CL, Elmer GI, Golani I (2003) SEE locomotor behavior test discriminates C57BL/6 J and DBA/2 J mouse inbred strains across laboratories and protocol conditions. Behav Neurosci 117:464-477

Kida E, Rabe A, Walus M, Albertini G, Golabek AA (2013). Long-term running alleviates some behavioral and molecular abnormalities in Down syndrome mouse model Ts65Dn. Exp Neurol 240:178-189.

Kleschevnikov AM, Belichenko PV, Gall J, George L, Nosheny R, Maloney MT, Salehi A, Mobley WC (2012). Increased efficiency of the GABAA and GABAB receptor-mediated neurotransmission in the Ts65Dn mouse model of Down syndrome. Neurobiol Dis 45:683-691.

Korenberg JR, Chen XN, Schipper R, Sun Z, Gonsky R, Gerwehr S, Carpenter N, Daumer C, Dignan P, Disteche C et al (1994) Down syndrome phenotypes: the consequences of chromosomal imbalance. Proc Natl Acad Sci USA 91:4997-5001

Lanfranchi S, Jerman O, Dal Pont E, Alberti A, Vianello R (2010). Executive function in adolescents with Down Syndrome. J Intellect Disabil Res 54:308-319.

Lavenex PB, Bostelmann M, Brandner C, Costanzo F, Fragniere E, Klencklen G, Lavenex P, Menghini D, Vicari S (2015). Allocentric 
spatial learning and memory deficits in Down syndrome. Front Psychol $6: 62$.

Lipp HP, Wahlsten D (1992) Absence of corpus callosum. In: Driscoll P (ed) Genetically defined animal models of neurological disorders. Birkhauser, Boston, pp 152-174

Liu C, Belichenko PV, Zhang L, Fu D, Kleschevnikov AM, Baldini A, Antonarakis SE, Mobley WC, Yu YE (2011). Mouse models for Down syndrome-associated developmental cognitive disabilities. Dev Neurosci 33:404-413.

Lyle R, Bena F, Gagos S, Gehrig C, Lopez G, Schinzel A, Lespinasse J, Bottani A, Dahoun S, Taine L, et al. (2009). Genotype-phenotype correlations in Down syndrome identified by array CGH in 30 cases of partial trisomy and partial monosomy chromosome 21. Eur J Human Genet 17:454-466.

Lyon L, Saksida LM, Bussey TJ (2012) Spontaneous object recognition and its relevance to schizophrenia: a review of findings from pharmacological, genetic, lesion and developmental rodent models. Psychopharmacology 220:647-672

Makanjuola RO, Hill G, Maben I, Dow RC, Ashcroft GW (1977) An automated method for studying exploratory and stereotyped behaviour in rats. Psychopharmacology 52:271-277

Matynia A, Kushner SA, Silva AJ (2002) Genetic approaches to molecular and cellular cognition: a focus on LTP and learning and memory. Annu Rev Genet 36:687-720

Maxson SC,Canastar A (2003). Conceptual and methodological issues in the genetics of mouse agonistic behavior. Horm Behav 44:258-262.

Menghini D, Costanzo F, Vicari S (2011) Relationship between brain and cognitive processes in Down syndrome. Behav Genet 41:381-393

Mezei G, Sudan M, Izraeli S, Kheifets L (2014). Epidemiology of childhood leukemia in the presence and absence of Down syndrome. 


\section{Cancer Epidemiol 38:479-489.}

Milner B, Squire LR, Kandel ER (1998) Cognitive neuroscience and the study of memory. Neuron 20:445-468

Nokia MS, Wikgren J (2010) Hippocampal theta activity is selectively associated with contingency detection but not discrimination in rabbit discrimination-reversal eyeblink conditioning. Hippocampus $20: 457-460$

Olson LE, Richtsmeier JT, Leszl J, Reeves RH (2004) A chromosome 21 critical region does not cause specific Down syndrome phenotypes. Science 306:687-690

Olson LE, Roper RJ, Sengstaken CL, Peterson EA, Aquino V, Galdzicki Z, Siarey R, Pletnikov M, Moran TH, Reeves RH (2007). Trisomy for the Down syndrome 'critical region' is necessary but not sufficient for brain phenotypes of trisomic mice. Human Mol Genet 16:774-782.

Palisano RJ, Walter SD, Russell DJ, Rosenbaum PL, Gemus M, Galuppi BE, Cunningham L (2001) Gross motor function of children with down syndrome: creation of motor growth curves. Arch Phys Med Rehabil $82: 494-500$

Palkovits M, Brownstein MJ (1988). Maps and guide to microdissection of the rat brain New York, Elsevier.

Patterson T, Rapsey CM, Glue P (2013). Systematic review of cognitive development across childhood in Down syndrome: implications for treatment interventions. J Intellect Disabil Res 57:306-318.

Paxinos G, Franklin KBJ (2004). The mouse brain in stereotaxic coordinates, Compact. 2nd edn. Elsevier Academic Press, Amsterdam

Peng GP, Feng Z, He FP, Chen ZQ, Liu XY, Liu P, Luo BY (2015). Correlation of hippocampal volume and cognitive performances in patients with either mild cognitive impairment or Alzheimer's disease. CNS Neurosci Ther 21:15-22. 
Pennington BF, Moon J, Edgin J, Stedron J, Nadel L (2003). The neuropsychology of Down syndrome: evidence for hippocampal dysfunction. Child Dev 74:75-93.

Pereira PL, Magnol L, Sahun I, Brault V, Duchon A, Prandini P, Gruart A, Bizot JC, Chadefaux-Vekemans B, Deutsch S, et al. (2009). A new mouse model for the trisomy of the Abcg1-U2af1 region reveals the complexity of the combinatorial genetic code of down syndrome. Human Mol Genet 18:4756-4769.

Poissonnier M, Saint-Paul B, Dutrillaux B, Chassaigne M, Gruyer P, de Blignieres-Strouk G (1976). [Partial trisomy 21 (21q21-21q22.2)]. Annales de genetique 19:69-73.

Reeves RH, Irving NG, Moran TH, Wohn A, Kitt C, Sisodia SS, Schmidt C, Bronson RT, Davisson MT (1995) A mouse model for Down syndrome exhibits learning and behaviour deficits. Nat Genet $11: 177-184$

Rigoldi C, Galli M, Condoluci C, Carducci F, Onorati P, Albertini G (2009) Gait analysis and cerebral volumes in Down's syndrome. Funct Neurol 24:147-152

Rosin JM, McAllister BB, Dyck RH, Percival CJ, Kurrasch DM, Cobb J (2015) Mice lacking the transcription factor SHOX2 display impaired cerebellar development and deficits in motor coordination. Dev Biol 399:54-67

Roubertoux PL, Carlier M (2009) Neurogenetic analysis and cognitive functions in Trisomy 21. In: Kim Y.K.K. (ed) Handbook of behavior genetics. Springer, New York, pp 175-185

Roubertoux PL, Carlier M (2010). Mouse models of cognitive disabilities in trisomy 21 (Down syndrome). Am J Med Genet Part C $154 \mathrm{C}: 400-416$.

Roubertoux PL, Sluyter F, Carlier M, Marcet B, Maarouf-Veray F, Cherif C, Marican C, Arrechi P, Godin F, Jamon M et al (2003) Mitochondrial DNA modifies cognition in interaction with the nuclear 
genome and age in mice. Nat Genet 35:65-69

Sago H, Carlson EJ, Smith DJ, Kilbridge J, Rubin EM, Mobley WC, Epstein CJ, Huang TT (1998) Ts1Cje, a partial trisomy 16 mouse model for Down syndrome, exhibits learning and behavioral abnormalities. Proc Natl Acad Sci USA 95:6256-6261

Sago H, Carlson EJ, Smith DJ, Rubin EM, Crnic LS, Huang TT, Epstein CJ (2000). Genetic dissection of region associated with behavioral abnormalities in mouse models for Down syndrome. Pediatr Res 48:606-613.

Sanderson DJ, Bannerman DM (2011). Competitive short-term and long-term memory processes in spatial habituation. J Exp Psychol Anim Behav Process 37:189-199.

Seregaza Z, Roubertoux PL, Jamon M, Soumireu-Mourat B (2006) Mouse models of cognitive disorders in trisomy 21: a review. Behav Genet 36:387-404

Siraly E, Szabo A, Szita B, Kovacs V, Fodor Z, Marosi C, Salacz P, Hidasi Z, Maros V, Hanak P et al (2015) Monitoring the early signs of cognitive decline in elderly by computer games: an MRI study. PloS ONE 10:e0117918

Smith DJ, Stevens ME, Sudanagunta SP, Bronson RT, Makhinson M, Watabe AM, O'Dell TJ, Fung J, Weier HU, Cheng JF et al (1997) Functional screening of $2 \mathrm{Mb}$ of human chromosome 21q22.2 in transgenic mice implicates minibrain in learning defects associated with Down syndrome. Nat Genet 16:28-36

Szklarczyk D, Franceschini A, Wyder S, Forslund K, Heller D, Huerta-Cepas J, Simonovic M, Roth A, Santos A, Tsafou KP, et al. (2015). STRING v10: protein-protein interaction networks, integrated over the tree of life. Nucleic Acids Res 43:D447-452.

Tsao R, Kindelberger C (2009). Variability of cognitive development in children with Down syndrome: relevance of good reasons for using the cluster procedure. Res Dev Disabil 30:426-432. 
Upchurch M, Wehner JM (1988) Differences between inbred strains of mice in Morris water maze performance. Behav Genet 18:55-68

Uyanik M, Bumin G, Kayihan H (2003) Comparison of different therapy approaches in children with Down syndrome. Pediatr Int 45:68-73

Vicari S (2006) Motor development and neuropsychological patterns in persons with Down syndrome. Behav Genet 36:355-364

Vicari S, Carlesimo GA (2006). Short-term memory deficits are not uniform in Down and Williams syndromes. Neuropsychol Rev 16:87-94.

Vis JC, Duffels MG, Winter MM, Weijerman ME, Cobben JM, Huisman SA, Mulder BJ (2009). Down syndrome: a cardiovascular perspective. J Int Disabil Res 53:419-425.

Volden PA, Wonder EL, Skor MN, Carmean CM, Patel FN, Ye H, Kocherginsky M, McClintock MK, Brady MJ, Conzen SD (2013).

Chronic social isolation is associated with metabolic gene expression changes specific to mammary adipose tissue. Cancer Prev Res 6:634-645.

Watanabe H, Fujiyama A, Hattori M, Taylor TD, Toyoda A, Kuroki Y, Noguchi H, BenKahla A, Lehrach H, Sudbrak R et al (2004) DNA sequence and comparative analysis of chimpanzee chromosome 22. Nature 429:382-388

Wehner, JM, Radcliffe, RA (2004). Cued and contextual fear conditioning in mice. Current protocols in neuroscience / editorial board, Jacqueline N Crawley [et al] Chap. 8, Unit 85 C.

Wehner JM, Radcliffe RA, Rosmann ST, Christensen SC, Rasmussen DL, Fulker DW, Wiles M (1997) Quantitative trait locus analysis of contextual fear conditioning in mice. Nat Genet 17:331-334

Weiss C, Disterhoft JF (2011) Exploring prefrontal cortical memory mechanisms with eyeblink conditioning. Behav Neurosci 125:318-326 
Wikgren J, Nokia MS, Penttonen M (2010) Hippocampo-cerebellar theta band phase synchrony in rabbits. Neuroscience 165:1538-1545

Yu T, Li Z, Jia Z, Clapcote SJ, Liu C, Li S, Asrar S, Pao A, Chen R, Fan $\mathrm{N}$, et al. (2010a). A mouse model of Down syndrome trisomic for all human chromosome 21 syntenic regions. Human Mol Genet 19:2780-2791.

Yu T, Liu C, Belichenko P, Clapcote SJ, Li S, Pao A, Kleschevnikov A, Bechard AR, Asrar S, Chen R et al (2010b) Effects of individual segmental trisomies of human chromosome 21 syntenic regions on hippocampal long-term potentiation and cognitive behaviors in mice. Brain Res 1366:162-171

Zhang L, Meng K, Jiang X, Liu C, Pao A, Belichenko PV, Kleschevnikov AM, Josselyn S, Liang P, Ye P, et al. (2014). Human chromosome 21 orthologous region on mouse chromosome 17 is a major determinant of Down syndrome-related developmental cognitive deficits. Human Mol Genet 23:578-589. 